\title{
Inventory of onshore petroleum seeps and stains in Greenland: a web-based GIS model
}

\author{
Flemming G. Christiansen ${ }^{\star+}[$, Jørgen A. Bojesen-Koefoed (1) \\ Geological Survey of Denmark and Greenland (GEUS), Copenhagen, Denmark
}

\begin{abstract}
A new inventory on onshore petroleum seeps and stains in Greenland has been released by the Geological Survey of Denmark and Greenland as a webbased GIS model on the Greenland Mineral Resources Portal: Petroleum Seeps and Stains in Greenland. Knowledge on oil and gas seeps, oil stains and solid bitumen occurrences provides key information on mineral and petroleum systems, especially in frontier basins. As the understanding of recent and previous migrations of fluids and gases is important for both mineral and petroleum explorations in Greenland, this new inventory has been developed to facilitate exploration and new activities. The classification includes the following types of occurrences: (1) oil seeps, (2) gas seeps, (3) mud diapirs, pingos and gas-rich springs, (4) oil stains in volcanics, carbonates and sandstones, (5) solid macroscopic bitumen and (6) fluid inclusions and other evidence of micro-seepage. The inventory comprises detailed information on localities, coordinates and sample numbers. It also includes descriptions of features and geology, references to data, reports and publications. All information is summarised in either a mineral or petroleum systems context. Petroleum seeps and stains have been reported from most Palaeozoic, Mesozoic and Cenozoic basins in Greenland where they add important information on petroleum systems, especially distribution and facies variation of source rocks, petroleum generation and later migration, accumulation, remigration, uplift and degradation. The inventory is designed to be updated with additional localities and descriptions and new organic geochemical data. This paper provides a general overview of classification, nomenclature, organisation and content of the inventory. We introduce the regional distribution of petroleum seeps and stains in Greenland and general interpretations in the context of mineral and petroleum systems.
\end{abstract}

\section{Introduction}

Knowledge on oil and gas seeps, oil stains and solid bitumens provides important information on petroleum systems in most sedimentary basins and may be of great importance in petroleum exploration, especially in frontier areas with no or limited drilling history. In the early part of modern petroleum exploration history, more than a century ago, seepage was an important factor for targeting drilling locations together with surface structural features. Most prolific onshore basins in, for example, Venezuela, Iran,
'Present address: Bygholmvej 15, 2720 Vanløse, Denmark *Correspondence: flemminggc@hotmail. com Received: 15 Dec 2020

Accepted: 09 Jul 2021 Published: 23 Sept 2021

Keywords: Greenland, organic geochemistry, petroleum and mineral systems, petroleum seeps and stains, solid bitumens

\section{Abbreviations: \\ BGR: Federal Institute for Geosciences and Natural Resources \\ CASP: Cambridge Arctic Shelf Programme GCMS: Gas chromatography mass spectrometry GCMSMS: Gas chromatography-tandem- mass spectrometry GEUS: Geological Survey of Denmark and Greenland GGU: Geological Survey of Greenland GMOM: Greenland Minerals Occurrence Map MVT: Mississippi Valley Type deposits SEDEX: Sedimentary exhalative deposits Tmax: Thermal maturity parameter \\ GEUS Bulletin is an open access, peer- reviewed journal published by the Geological Survey of Denmark and Greenland (GEUS). This article is distributed under a CC-BY 4.0 licence, permitting free redistribution, and reproduction for any purpose, even commercial, provided proper citation of the original work. Author(s) retain copyright.}

Edited by: Michael B.W. Fyhn (GEUS, Denmark)

Reviewed by: Dag Arild Karlsen (University of Oslo, Norway) \& one anonymous reviewer.

Funding: See page 16

Competing interests: See page 17

Additional files: See page 17 
Iraq and central and western US show some surface expressions of petroleum (Link 1952; Gussow 1954; Hunt 1979; Macgregor 1993).

Throughout the last three to four decades, seep materials from all over the world have been analysed and classified by applying modern biomarker analyses (Peters et al. 2004 and references therein) and discussed in the context of petroleum systems (Abrams 2005; Schumacher \& Abrams 2006). Such seep data may add important information concerning distribution and facies variation of source rocks in the subsurface, thermal maturity of source rocks, vertical and lateral migration of generated petroleum and later biodegradation or thermal alteration.

The first brief observations on seepage and solid bitumens in Greenland go many decades back, see historical comments by, for example, Henderson (1969, 1976), Mikkelsen (1993) and Bojesen-Koefoed et al. (2006). Systematic field studies combined with modern organic geochemistry began in East and North Greenland in the early and mid-1980s and in West Greenland in the early 1990s by the present authors and have continued since. At the Geological Survey of Denmark and Greenland (GEUS), the standard routine for most samples collected by GEUS-geologists has been systematic screening by Rock Eval pyrolysis. Those samples with low Tmax (thermal maturity parameter from Rock Eval pyrolysis) and high Production Index (a parameter for hydrocarbons already present from Rock Eval pyrolysis) are then chosen for more detailed organic geochemistry. Christiansen (1994) gave a first review of seeps and other bitumen showings in Greenland and provided an overview of the geochemical analyses that were available at that time. Seep studies are very important in first evaluations of the petroleum potential of many basins, and in the process of attracting industry interest to Greenland exploration (Christiansen 2011).

Understanding the distribution of solid bitumen occurrences as the result of migration of basinal brines or hydrothermal circulation in sedimentary basins is also important for mineral exploration, especially for $\mathrm{Pb}, \mathrm{Zn}, \mathrm{Cu}, \mathrm{Ag}$ and Au. Many records of solid bitumen come from the studies of either sedimentary exhalative (SEDEX) deposits or Mississippi Valley-Type (MVT) deposits (e.g. Parnell 1988; Jakobsen \& Omoto 1993; Gregg 2004; Paradis et al. 2007; Gregg \& Shelton 2012). The role of hydrocarbon compounds during the mineralisation processes is not fully understood in all cases, but likely reflects movements of fluids in faults as known from Kongsberg, Norway (Ag/bitumen), Almaden, Spain (Hg/ bitumen) and Cornwall (Sn/bitumen). The mineralising deep-basinal brines are often similar in composition and salinity to oil field brines. Circulation of hydrothermal fluids with significant amounts of hydrocarbons influences sulphate reduction, and thereby the mineral precipitation in the host rocks, usually fractured dolomite.

Solid bitumen is also common not only in uraniferous mineralisations (Landais 1993, 1996; Alexandre \& Kyser 2006), including various sandstone and conglomerate facies, but also in veins associated with granitic or syenitic intrusions. The role of bitumen and the timing of mineralisation processes are not always clear, but it seems that the interaction between hydrocarbon compounds and uranium-carrying solutions provides good possibilities for co-precipitation of uraniferous mineralised and bitumen under reducing conditions. Else, the uranium could precipitate on the surface of previously formed solid bitumen. It is well known that porphyrins in oil carry uranium and other elements like $\mathrm{Ni}$ and $\mathrm{V}$, as these were incorporated in the paleo-depositional source-rock environment. These metals are generally water soluble in their oxidised state, while they precipitate under reducing conditions.

Graphite found in mineralisations formed by interaction between organic-rich sediments and magmas is not mentioned in the inventory. Some of these occurrences are common in the Nuussuaq Basin, for example, the graphite andesite in the Aaffarsuaq valley on Nuussuaq (Pedersen et al. 2017). Graphite occurrences are common elsewhere in Greenland, some associated with organic-rich sources and others clearly abiogenic (see overview in Thrane \& Kalvig 2019).

As the understanding of both recent and previous movements of fluids and gases in sedimentary basins in Greenland is important in exploration for petroleum and minerals - and for understanding of both minerals and petroleum systems - an inventory of petroleum seeps and stains has been developed at GEUS to facilitate new exploration models and activities. The inventory, Petroleum Seeps and Stains in Greenland, has now been released in a GIS-format on the Greenland Mineral Resources Portal and can be accessed at https:// doi.org/10.22008/FK2/JKYXJM.

The inventory includes a systematic description of $c$. 130 localities or small areas across Greenland (Fig. 1). So far, 52 localities from North Greenland are described (selected examples are shown in Fig. 2A), 23 in East and North-East Greenland (selected examples are shown in Fig. 2B), 54 in West Greenland (selected examples are shown in Fig. 2C; 11 on Svartenhuk Halvø, one on Qeqertarsuaq, three on Schades Øer, seven on Ubekendt Ejland, 24 on Nuussuaq, two on Hareøen and six on Disko) and two in South and South-West Greenland. For full details of each locality, see the inventory.

More than 500 field samples and core pieces have so far been analysed geochemically or described by microscopy. This number is steadily growing. This paper provides a general overview of classification, nomenclature, 


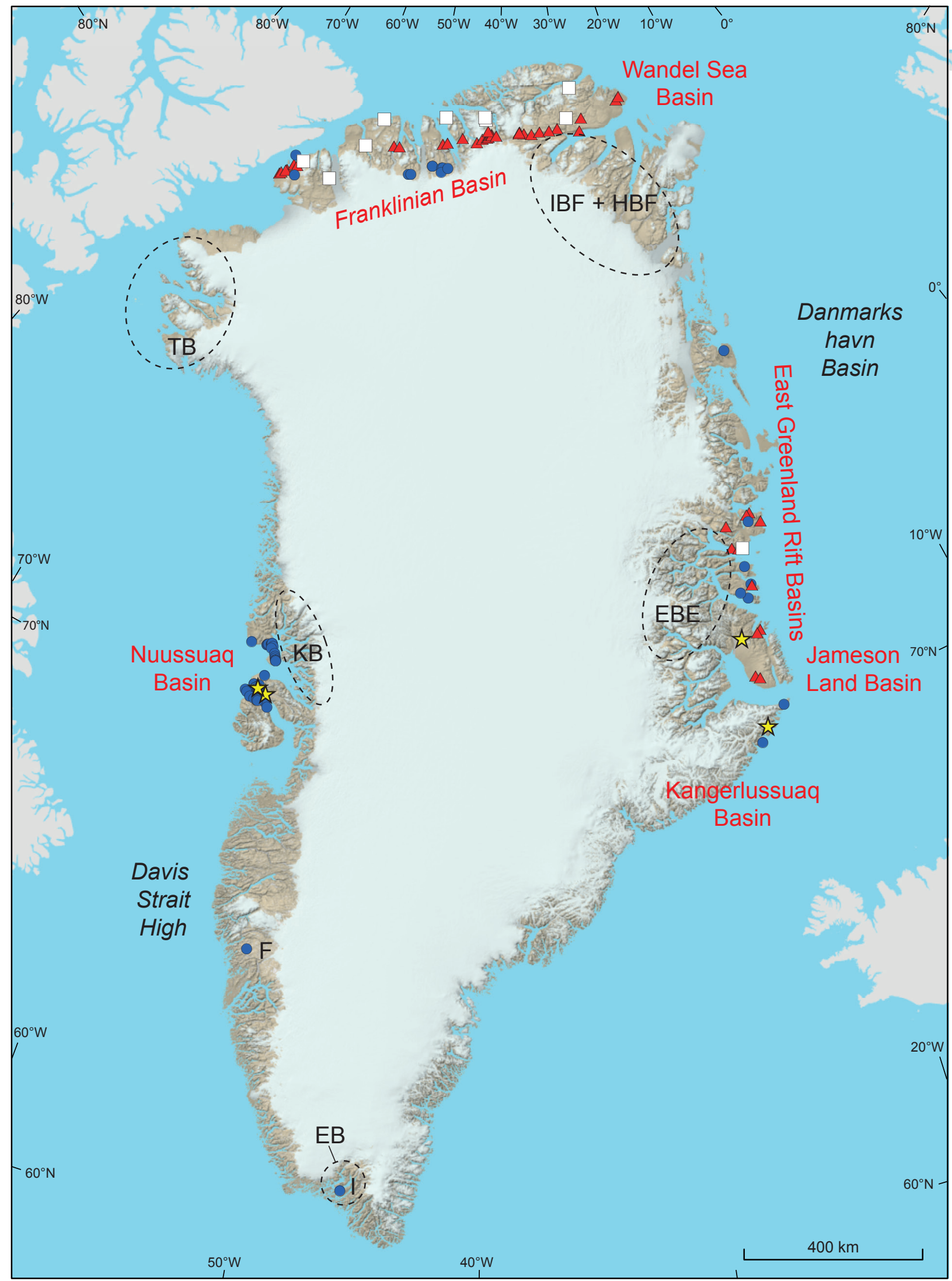

Fig. 1 Map of Greenland showing distribution of petroleum steeps and stains. Red triangles: Petroleum seepage and stains associated with source rock. Blue circles: Petroleum seeps and stains, migrated. White squares: Solid bitumen associated with mineral occurrences. Yellow stars: Gas seepage and gas-rich springs. Red text: Basins with petroleum seeps or stains including Nuussuaq Basin, Franklinian Basin, Wandel Sea Basin, East Greenland rift basins, Jameson Land Basin and Kangerlussuaq Basin. Dotted black lines: Outline of Proterozoic basins or their main outcrop area without petroleum seeps and stains. EB: Eriksfjord basin. KB: Karrat basin. TB: Thule Basin. IBF: Independence Fjord Basin. HFB: Hagen Fjord Basin. EBB: Eleonora Bay Basin. F: Fossilik. I: llímaussaq. 

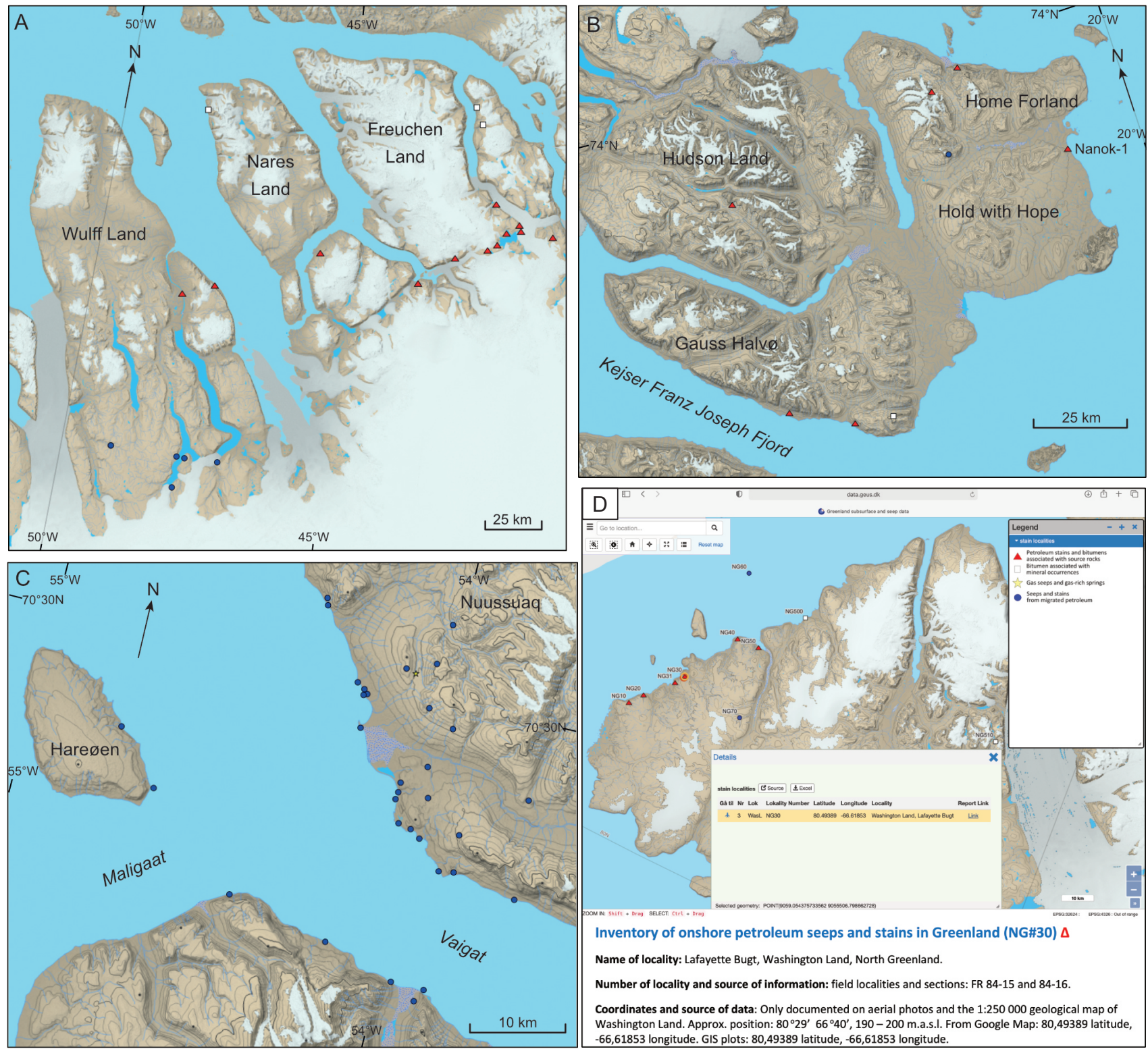

Fig. 2 Close up examples from the web-based GIS model, in this case with a topographic map as background. A: Franklinian Basin, North Greenland encompassing: Wulff Land - Nares Land - Freuchen Land region. B: East Greenland rift basins, North-East Greenland encompassing: Hold with Hope region. C: Nuussuaq Basin, West Greenland encompassing: northern Disko (base of map) western Nuussuaq - Hareøen region. D: Text examples (with screen dumps of maps) from the Franklinian Basin, North Greenland (site NG30 on Washington Land). Red triangles: Petroleum seepage and stains associated with source rock. Blue circles: Petroleum seeps and stains, migrated. White squares: Solid bitumen associated with mineral occurrences. Yellow stars: Gas seepage and gas-rich springs.

organisation and content of the inventory, and an introduction to the regional distribution of petroleum seeps and stains in Greenland with general interpretations in the context of mineral and petroleum systems.

\section{Classifications and nomenclature}

Seepage features and the various sorts of bitumen occurrences have historically followed different classification systems. Some are old and generic (see Christiansen 1994), whereas most new studies focus directly on the detailed organic geochemistry, understanding of processes and the implications to the petroleum systems.

Many countries have petroleum seepage inventories, for example, Great Britain (Selley 1992), Italy (Burrato et al. 2013), Romania (Ionescu et al. 2017), China (Zheng et al. 2018) and Turkey (Palabiyik \& Ozdemir 2019). In Greenland, it is necessary to use a modified classification system or nomenclature that can be applied in accordance with the special conditions experienced there. The main reason for this is the Arctic climate with 
very cold winter temperatures, short cool summers and, apart from some snow, rather dry conditions. Consequently, most onshore sedimentary basins in West and East Greenland have several tens of metres thick permafrost - in North Greenland, the permafrost is several hundred metres thick. The low temperatures, extensive permafrost, effects of recent glaciations and intense erosion along coasts and in mountain terrains seem to reduce biodegradation of many petroleum seeps or stains. Recent glacial erosion has also resulted in modification of outcrops and uplift.

Organic geochemical analysis is, therefore, a strong exploration tool in Greenland compared to regions with warmer and more humid climate, resulting in extensive hydrocarbon degradation. However, knowing that the permafrost may define a secondary seal for shallow oil and gas accumulations and, thus, also impede remigration of oil and gas to the surface, seep data should be interpreted cautiously with respect to defining local drilling targets.

In this inventory, we also include information from fully cored boreholes down to a few hundred metres as some of these penetrate sedimentary or volcanic units that often crop out nearby. Many of the stratigraphic boreholes from systematic source-rock studies that have been drilled by GEUS over the years (Bojesen-Koefoed et al. 2014, 2018, 2020; Christiansen et al. 2020a) show petroleum stains. This is also the case for boreholes drilled during mineral or petroleum exploration. Whenever possible, we try to distinguish between the following types of occurrences:

1. Oil seeps. Classical oil seeps are rare in Greenland. Due to the low temperatures, surface oils have a high viscosity, and in many cases, they are solid or even brittle. Many remote seep localities have not been revisited, and it is difficult to evaluate the level of activity. Some important localities that have been revisited after initial field work show change from year to year, for example, Marraat in the Nuussuaq Basin. This indicates the presence of active or 'live' seeps. However, that activity is probably restricted to a few warm, sunny days (Figs 3A-E).

2. Gas seeps. This type of seepage is rare if at all present in Greenland. Most examples of gas are related to gas-rich springs and possibly only with activity in shorter periods of the year (i.e. summer to early autumn).

3. Mud diapirs, pingos and other periglacial features and gas-rich springs. Pingos and other periglacial features share some characteristics with oil- and gas-bearing mud diapirs from prolific petroliferous basins in Azerbaijan or Romania. Pingos are found in many valleys in West and East Greenland (Bennike 1998).
Pingos in Greenland occasionally show gas bubbles from 'crater' lakes or gas-rich water from springs on the side of the pingos (Figs 3F, G; see also figs 8A, B in Christiansen et al. 2020a). Sometimes gas escape structures or small mounds are observed on either muddy or sandy flats (see figs 12A, B in Christiansen et al. 2020a). Direct evidence of associated petroleum such as iridescence or oil drops on the water surface has not been reported from Greenland so far, despite systematic searches.

4. Oil stains in volcanics, carbonates and sandstones. This type of petroleum is the most common in Greenland. Oil stains in volcanics are particularly common in the Nuussuaq Basin in West Greenland (Figs $3 \mathrm{H}-\mathrm{J}$ ), whereas oil stains in carbonates are often found in Cambrian-Silurian strata of the Franklinian Basin in North Greenland, and in the Upper Permian succession of the East Greenland rift basin. Oil-stained sandstones are recorded from many different localities and boreholes in North, East and West Greenland (see, e.g. fig. 6 in Bojesen-Koefoed et al. 2020).

5. Solid macroscopic bitumen (or pyrobitumen) in mineralised carbonate veins and fractures and in rocks with macro-porosity. This is observed in corals and other fossils, vesicular lavas and partly open fractures (e.g. fig. 6 in Christiansen \& Rolle (1985), plates 7, 8 and 9 in Christiansen (1989) and fig. 4A in Christiansen \& Stemmerik (1989)). Such types are common in Greenland, especially in deeply eroded sedimentary basins with a relatively high thermal maturity such as those found in North and North-East Greenland. Solid pyrobitumen is also commonly associated with $\mathrm{Pb}-\mathrm{Zn}$-Cu mineralisation in veins and fractures in carbonate rocks, especially in North and East Greenland (see fig. 5 in Jakobsen \& Omoto (1993)).

6. Fluid inclusions and other evidence of micro-seepage. Recognising this type requires a systematic search. Hammering on specific healed and mineralised fractures combined with an instant check for petroliferous odour on warm sunny days has disclosed many such localities in the volcanic rocks of the Nuussuaq Basin in West Greenland. Most examples have been confirmed later by detailed organic geochemical analyses. Such systematic searches have also been applied to outline areas that do not show any apparent evidence of petroleum (i.e. a negative check).

In addition to the overall classification, we describe if the petroleum stains and solid bitumen occurrences have an origin from a nearby local source rock that is thermally mature or postmature, with respect to petroleum generation. We describe whether this is due to intrusions of dykes or sills or because the exposed 

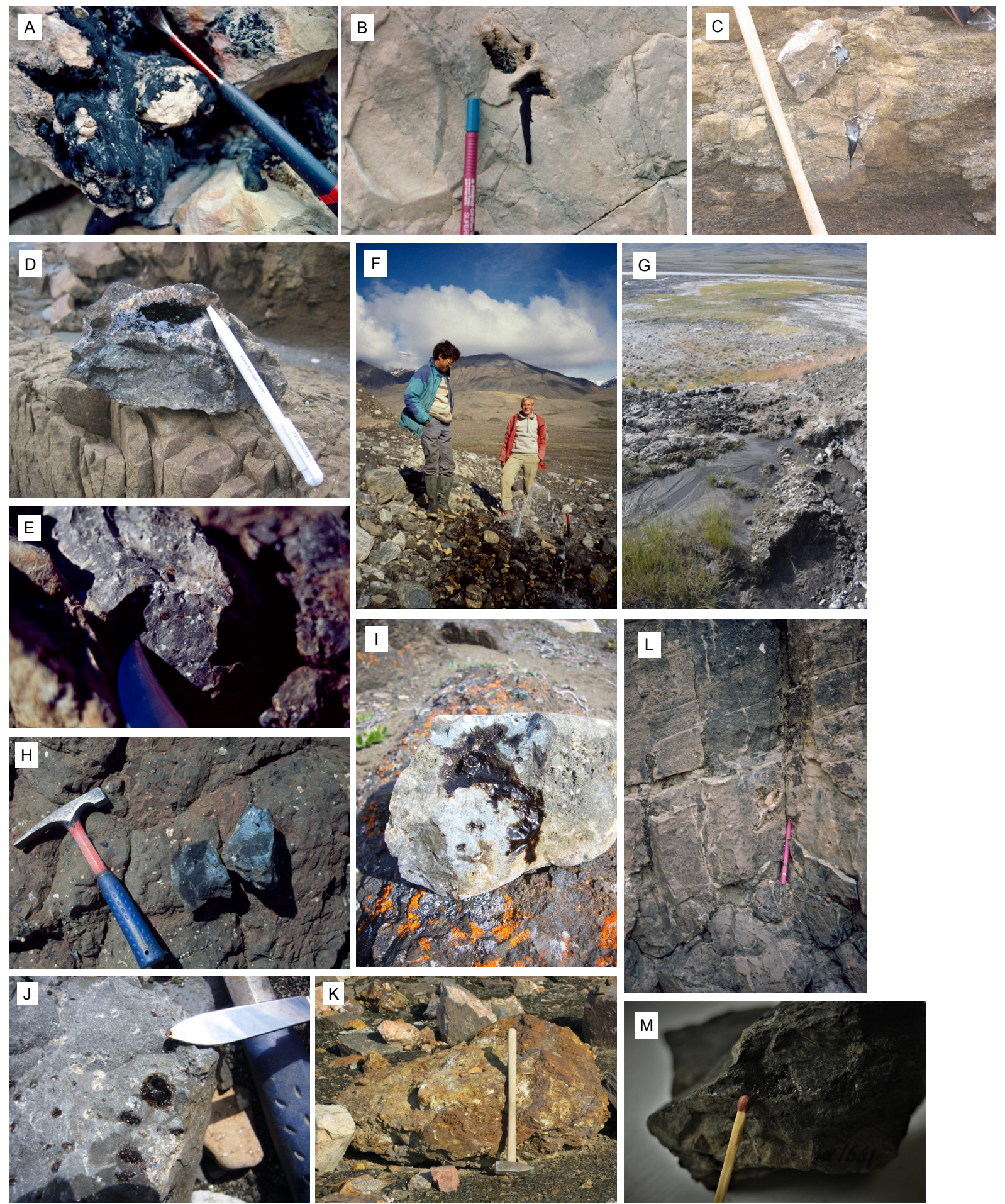

Fig. 3 Collection of field photos showing petroleum seepage and stains from Greenland. All photos are by the authors unless otherwise specified. Dates are indicated as some of the features are known to change over time. A: Asphalt seep from Portfjeld Formation in southern Wulff Land, North Greenland (sample 324200), 18 August 1985. B: Asphalt oozing out of partly dolomite filled vug, Portfjeld Formation in southern Wullf Land, North Greenland (sample 324200), 18 August 1985. C: Oil seepage from Marraat discovery point, Nuussuaq, West Greenland, 10 August 2004. D: Petroleum oozing out of large vug in basalt from Marraat discovery point, Nuussuaq, West Greenland, 10 August 2004. E: Petroleum oozing out of fracture at Kuugannguaq valley, Disko, West Greenland, 14 July 1996. F: Water spring with gas seepage from Aaffarsuaq valley, Nuussuaq, West Greenland, 26 July 2019. G: Small pools rich in gas on the side of a pingo in the Aaffarsuaq valley, Nuussuaq, West Greenland. Blooming algae and vegetation downstream indicate that the water is rich in nutrients, 26 July 2019. H: Oil oozing out of freshly broken pillow breccia, Nuussuaq, West Greenland, 18 July 1996. I: Oil oozing out of freshly broken boulder on the beach at Sikillingi, Nuussuaq, West Greenland, 19 July 2006. J: Oil oozing out of freshly broken boulder on the beach at Sikillingi, Nuussuaq, West Greenland, 23 July 2006. K: Rusty basement rocks with solid bitumen from Flade Bugt, Germania Land, 12 August 2009. L: Large quartz crystals and solid bitumen (at the point of pencil) in dolomite of the Gråklint Member in Mols Bjerge, East Greenland, 5 August 1986. M: Dolomite with solid bitumen, Gråklint Member, Buch Bjerg. 
sediments have a regionally high thermal maturity due to subsidence and later uplift.

Many petroleum stains and solid bitumens are, however, not closely associated with source rocks and are likely to be the result of significant vertical or lateral petroleum migration, typically on a scale from a few kilometres to tens of kilometres. Correlation of such petroleum stains and solid bitumens to either known or inferred source rocks is particularly important for understanding the basin history. Such correlations can be made by detailed organic geochemistry, either to a known source rock or, in some cases only, to inferred source rocks that are generally interpreted in terms of depositional environment and age.

\section{Inventory}

The first step in compiling the inventory was a systematic check of all known publications and reports, and thereby identifying observations, analyses, sample numbers and localities. Most field or analytical information has been published or reported internally at GEUS, especially concerning samples collected during major expeditions and systematic resource evaluations. Furthermore, a large in-house sample database at GEUS, containing >100 000 samples collected by hundreds of geologists over many decades, was checked using search words like pyrobitumen, bitumen, bituminous, petroliferous and oily.

In some cases, field geologists with long experience in Greenland geology were interviewed. The Greenland Mineral Occurrence Map (GMOM; accessible at http:// www.greenmin.gl/) provided by GEUS was also checked systematically for information and descriptions.

All samples were assigned to specific localities - or groups of similar localities within shorter distances of some hundred metres, either using aerial photographs, topographic and geological maps of various vintage and for samples collected since the mid-1990s, directly to GPS coordinates. All locations from fieldwork before the mid-1990s - or groups of localities and measured sections - have been georeferenced to modern coordinates by replotting on modern maps or recalculated from various old Universal Transverse Mercator (UTM) coordinates or geographical coordinates. In a few cases, georeferencing was done by Google Maps`. Wherever possible, the primary sources of information together with recalculations have been documented. The original measured altitudes were used. Most samples from West Greenland are close to sea level, so altitude is only indicated for localities higher than $25 \mathrm{~m}$ above sea level.

Some uncertainties remain in the precise identification of coordinates, especially for localities in East and North-East Greenland. It is, thus, recommended to check the primary source of information (original maps or photos) in detail, prior to planning any new field work.
Where possible, the most recent stratigraphical nomenclature is used following Watt (2019), but still with reference to the original description when needed for a full understanding. The geographical and basin nomenclature also follows Watt (2019).

The inventory is documented as a GIS compilation, where the user can select to show the distribution of petroleum seeps on the top of standard topographic or geological maps, and other optional data and place names. For each locality, there is a link to the description and classification of features and interpretations. Examples of maps exported from the inventory are shown in Figs $2 \mathrm{~A}-\mathrm{C}$, and an example of the text description obtained from the inventory is shown in Fig. 2D. Where possible, descriptions include photos or references to published photos, references to organic geochemical data, reports and publications.

All previous analytical data from GEUS have been rechecked, not only for quality control and possible contamination but also to update interpretations where more recent data are available. Interpretations within a general context of petroleum or mineral systems are provided wherever possible with a special focus on the origin of petroleum and bitumen (source rocks or other organic-rich units).

\section{Regional distribution of petroleum seeps and stains in Greenland}

Petroleum seeps and stains have been reported from most Palaeozoic, Mesozoic and Cenozoic onshore basins in Greenland, see regional descriptions in sections 5.1, 6.1 and 7.1, and where possible are presented in stratigraphic order. Generally, the seeps and stains provide additional information to the petroleum systems of these basins, especially as a documentation of the generative potential of both known and inferred source rocks.

So far, there are no analytically confirmed examples of petroleum seeps or stains from Proterozoic basins such as the Eriksfjord basin in South Greenland, the Karrat basin in West Greenland, the Thule, Independence Fjord and Hagen Fjord basins in North Greenland and the Eleonora Bay basin in North-East Greenland (Fig. 1). This is probably because these basins only have few, and in most cases not known, organic-rich mudstones. Furthermore, these basins have a long and complex structural and thermal history with relatively high thermal maturities. Thus, if such samples existed, the bitumen would be radically altered. In this context, we do not consider if graphite represents altered bitumen.

A few examples of dark bituminous material in fractures have, however, been mentioned from the Eleonora Bay basin (M. Sønderholm, personal communication 2020) in Caledonian basement in Stauning Alper west of 
Jameson Land and in intrusions in South Greenland (see Section 6.1). The origin of this bitumen is uncertain but is most likely related to generation from much younger source rocks.

\section{North Greenland}

\subsection{Petroleum seeps and stains}

Petroleum seeps and stains are common in the Lower Palaeozoic Franklinian Basin in North Greenland (Christiansen 1989; Christiansen et al. 1989b). Examples have been reported from Washington Land in the west to Peary Land in the east (Figs 1, 2A), with records from more than 40 localities. The petroleum seeps and stains occur mainly as three types in distinct geological settings (Fig. 4):

1. Solid bitumen and intense staining or impregnation of carbonates or sandstones closely associated with mature to postmature Cambrian source rocks from the Henson Gletscher Formation in southern Freuchen Land and westernmost Peary Land (Christiansen et al. 1987, 1989b). All examples suggest a maximum vertical migration from the source rock of only a few hundred metres. The organic geochemical composition and measured reflectance of the bitumen samples are in accordance with the regional thermal maturity of the source rock (Christiansen et al. 1987, 1989a; Christiansen 1988).

2. Soft to solid bitumen closely associated with mature to postmature Silurian source rocks in either the Lafayette Bugt Formation or the Thors Fjord Member of the Wulff Land Formation. Such bitumen occurrences are widely distributed throughout North Greenland from Washington Land in the west to Peary Land in the east (Christiansen \& Nøhr-Hansen 1989; Christiansen et al. 1989b; Stemmerik et al. 1997). All examples suggest a maximum vertical migration from the source rock of only a few hundred metres. The organic geochemical composition and measured reflectance of the bitumen are in accordance with the regional thermal maturity of the source rock (Christiansen 1988; Christiansen et al. 1989a).

3. Petroleum seepage and stains in immature Cambrian or Ordovician strata, especially from the Portfjeld and Buen formations, in the southern part of Warming Land and Wulff Land (Figs 3A, B) but possibly also further to the east and west. These examples of migrated oil are all supposed to be the result of long-distance migration from a yet unknown mature Lower Palaeozoic source rock (Christiansen et al. 1989b).

In addition to the many such examples described and published by Christiansen et al. (1989b), a number of samples have been collected later in western and central Peary Land (unanalysed or unreported), especially black carbonates and solid bitumens in the Henson Gletscher Formation (c. type 1) and also petroleum stains from older sandstones (c. type 3), and solid bitumens from Silurian carbonates of the Samuelsen $\mathrm{H} ø$ j Formation (c. type 2). Furthermore, several carbonate build-ups with pore spaces filled with bitumen have been found in southern Pentamerus Bjerge and southwards to Kap Jefferson, Washington Land, documented as part of the Kane project (Dawes et al. 2000). Samples are still to be analysed, but most likely the bitumen is closely related to Silurian source rocks (c. type 2). During the ARK-XXV/3 cruise with Polarstern in 2010, geologists from the Federal Institute for Geosciences and Natural Resources (BGR), Germany, sampled and subsequently carried out microscopy analysis of bituminous limestones from the Lafayette Bugt area (Kus \& Pletsch 2012).

Petroleum seeps and stains are rare in the Upper Palaeozoic - Cenozoic Wandel Sea Basin (Fig. 1). This is probably because the organic content of most sedimentary units is low, as only proximal facies crop out. Furthermore, regional thermal maturity is either very low (immature with respect to oil generation) or locally very high (postmature related to low metamorphic conditions in some thrust-sheets). A few examples of petroleum stains and solid bitumen have been reported from cores in the Triassic Dunken Formation (Dunken-2 borehole) and the Upper Permian Midnatsfjeld Formation (Kim Fjelde-1 borehole) in eastern Peary Land. Both occurrences are found in relatively lean mudstone successions with occasional richer intervals. Based on their biological marker signatures, the stains are considered in-situ and intraformational, being generated directly from the rocks in which they are hosted (J.A. Bojesen-Koefoed unpublished data 2013).

\subsection{Gas}

Gas seeps have not been recorded from North Greenland, and gas was not recorded during core drilling of 13 holes in 1985 (Christiansen et al. 1986). From this core drilling, it is known that near surface temperatures are -11 to $-14^{\circ} \mathrm{C}$, indicating that permafrost in this region is many hundreds of metres thick forming a thick secondary seal, if shallow gas is present. Only a few pingos are known this far north (Bennike 1998). Gas occurrences have not been systematically examined in relation to oil seeps (i.e. in the form of gas inclusions).

\subsection{Bitumen associated with mineral occurrences}

Solid bitumen has been found associated with several mineral occurrences in North Greenland (Fig. 1). One 

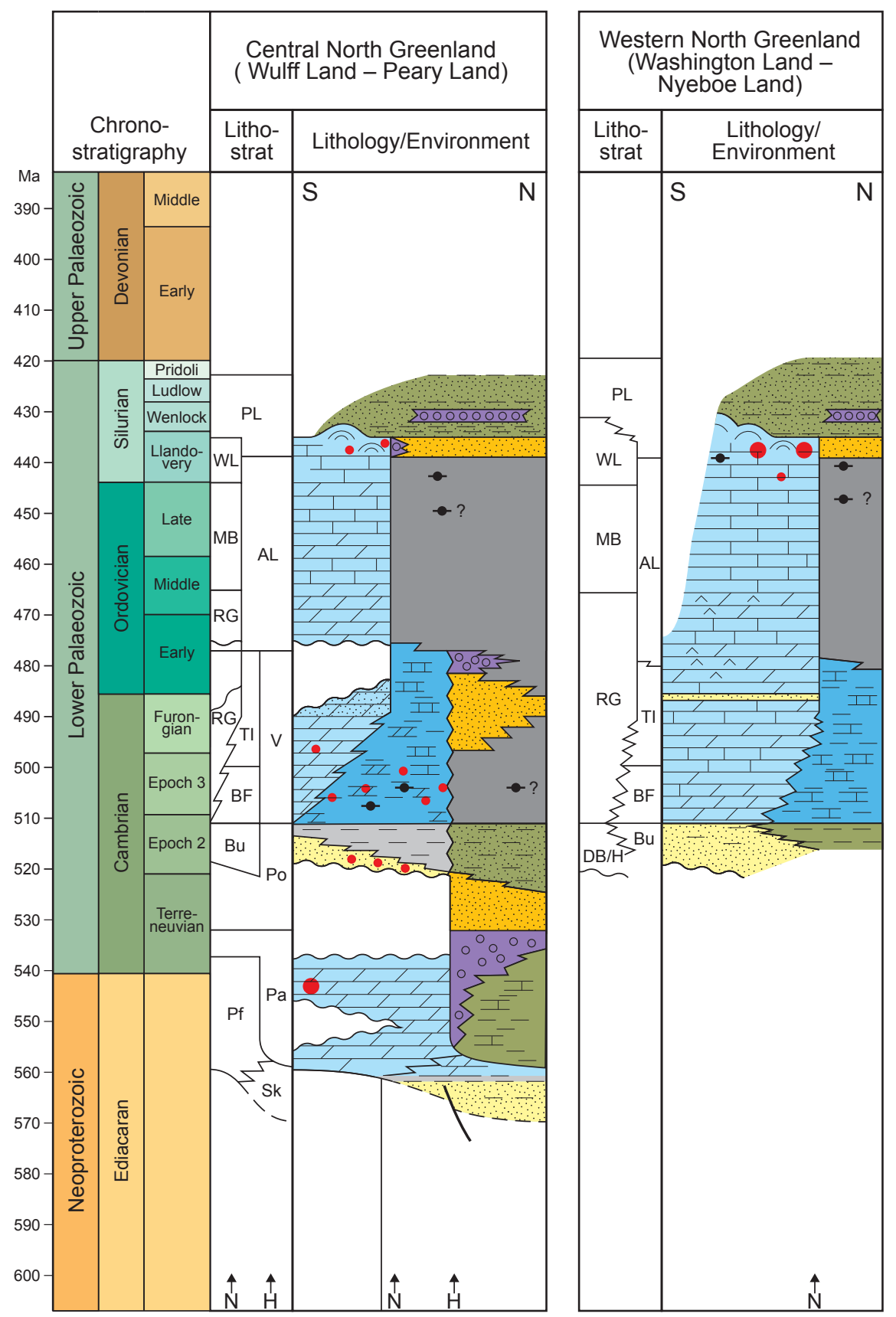

Fig. 4 Stratigraphy of North Greenland (Franklinian Basin) with simplified relations between petroleum seeps, stains and petroleum systems elements (modified from Christiansen 1989 and Hopper \& Ineson in press). AL: Amundsen Land Group. BF: Brønlund Fjord Group. Bu: Buen Formation. DB/H: Dallas Bugt and Humbolt Formations. MB: Morris Bugt Group. Pa: Paradisfjeld Group. Pf: Portfjeld Formation. PL: Peary Land Group. Po: Polkorridoren Group. RG: Ryder Gletscher Group. Sk: Skagen Group. Tl: Tavsens Iskappe Group. V: Vølvedal Group. WL: Washington Land Group.

\begin{tabular}{|c|c|}
\hline \multicolumn{2}{|c|}{ Lithology } \\
\hline 500 & Conglomerate \\
\hline & Sandstone \\
\hline- & Mudstone \\
\hline 1 & Limestone \\
\hline 7 & Dolostone \\
\hline$\curvearrowright$ & Mound \\
\hline$\lambda \wedge$ & Evaporite \\
\hline$\bullet$ & Source rock \\
\hline$\bullet$ & Major petroleum seep \\
\hline$\bullet$ & Minor petroleum stain \\
\hline
\end{tabular}

\section{Environmental domains}

\begin{tabular}{l}
\hline Shallow-water carbonate platform/ramp \\
\hline Slope deep shelf (carbonate/siliciclastic) \\
\hline Siliciclastic shelf (inner, sand-rich) \\
\hline Siliciclastic shelf (outer, mud-rich) \\
\hline Starved basin \\
\hline Sand-rich turbidite system \\
\hline Muddy turbidite system (including carbonates) \\
\hline Conglomeratic deep-water system \\
N Navarana Fjord Lineament \\
H Harder Fjord Lineament
\end{tabular}


example is a $\mathrm{Pb}-\mathrm{Zn}$ occurrence in the Navarana Fjord region (east of Freuchen Land, Fig. 2A) that has been described in detail by Jakobsen \& Steenfelt (1985) and Jakobsen \& Omoto (1993). Bitumen is associated with several stages of the mineralisation that formed from hot $\left(200^{\circ} \mathrm{C}\right)$ metal-bearing brines that migrated through veins and fractures. Sulphur isotope analysis suggests that the bitumen correlates with the same source rocks that have generated the long-distance migrated oils in southern Warming and Wulff Land (i.e. a c. type 3; Jakobsen \& Omoto 1993).

Solid pyrobitumen has also been recorded in other mineral occurrences such as the Citronen Fjord deposit, Peary Land (Van der Stijl \& Mosher 1998) and in association with $\mathrm{Zn}-\mathrm{Pb}-\mathrm{Ag}$ occurrences on Washington Land. Here, it is found in the Ordovician succession close to Petermann Gletscher in the east and in the Silurian succession at Kap Schuchert in the west (Jensen 1998). According to von Guttenberg \& van der Stijl (1993), bitumen has also been noted in $\mathrm{Zn}-\mathrm{Pb}$ mineral occurrences in different settings, including Silurian reefs at Kayser Bjerg, Hall Land, in Cambrian carbonate debris flows at Hand Bugt, northern Nyeboe Land and at Kap Wohlgemuth, northern Nares Land (Fig. 2A).

Based on the examples of mineral occurrences associated with solid bitumen in North Greenland, there seems to be a strong correlation between mineral and petroleum systems. Some systems are clearly associated with organic-rich Silurian mudstones (c. type 2). Others are related to organic-rich, thermally postmature, deep-water deposits of Cambrian or Ordovician age (c. type 3 ) in strongly folded or steeply dipping zones in the northern part of the Franklinian Basin. These occurrences are both of MVT and SEDEX types.

\section{East and North-East Greenland}

\subsection{Petroleum seeps and stains}

Petroleum seeps and stains are not only common in the rift basins in North-East Greenland and in the Jameson Land Basin (Fig. 1), especially along the eastern margin on Wegener Halvø, but also closely associated with exposed Jurassic source rocks in central and southern Jameson Land. Given the many organic-rich units in these basins, this is to be expected (Fig. 5). It should, however, be noted that several of the many potential source rocks do not have associated bitumen occurrences, probably due to a low thermal maturity in the areas where they crop out. This is the case for the Carboniferous lacustrine mudstones (Piasecki et al. 1990; Stemmerik et al. 1990), Jurassic resinite-rich coals (Bojesen-Koefoed et al. 1996; Petersen et al. 2002, 2013) and the Jurassic Sortehat Member (Krabbe et al. 1994), where associated bitumen is still not found. In total, 19 localities or small areas with petroleum seeps and stains have been reported so far.
Petroleum stains were discovered in a fault-zone in the metamorphic basement close to Flade Bugt on Germania Land by Henrik Stendal and Svend Monrad Jensen in 1990 (Fig. 3K). Preliminary organic geochemical studies showed that the petroleum stains are severely degraded, with a most likely origin from a saline lacustrine unit (Christiansen et al. 1991). More recent sampling followed by gas chromatography-tandem-mass spectrometry (GCMSMS) indicates that the oil was probably generated from marine shale source rocks of Jurassic Lower Cretaceous age (Bernbjerg Formation), broadly equivalent to the principal source rocks of the North Sea Graben systems (Bojesen-Koefoed et al. 2009). The stains may represent long-distance migration from the offshore Danmarkshavn Basin or generation from an ancient sedimentary cover, which has later been removed by erosion.

Organic-rich lacustrine mudstones of potential source-rock quality occur in two intervals in the Devonian succession: the Middle Devonian (Givetian) and the Upper Devonian (?Famennian; Christiansen et al. 1990a). In both cases, black solid bitumen in calcite veins is associated with the source rocks. Solid bitumen associated with Devonian lacustrine units on Canning Land has been mentioned by the Cambridge Arctic Shelf Programme (CASP).

Oil stains have been reported from a succession overlying the Upper Permian Ravnefjeld Formation at Kap Stosch in the north-western corner of Home Forland (Fig. 2B), within both Cretaceous sandstones and Paleocene basalts and sediments. One sample of basalt carries tar-like material in vesicles and another sample shows petroleum hosted by calcite veins in basalt. Biological marker data clearly link both occurrences to the Upper Permian Ravnefjeld Formation, which crops out in the area (Bojesen-Koefoed et al. 2009). The Upper Permian carbonates on Gauss Halvø contain black solid bitumen, and overlying Triassic sandstones are stained by oil; in both cases, unpublished biological marker data suggest the Upper Permian Ravnefjeld Formation as the source. Solid black bitumen is common in fractures and vugs in the Upper Permian carbonates and Lower Triassic sandstones on Wegener Halvø (Stemmerik et al. 1989; Scholle et al. 1991). These bitumen occurrences have been generated from the Ravnefjeld Formation source rock that has a high thermal maturity in this region ( $R_{0}$ : 1.4-1.8\%; Christiansen et al. 1990b). In contrast, the thermal maturity of the exposed Ravnefjeld Formation is low along the western margin of the Jameson Land Basin in Schuchert Dal, and no records of solid bitumen or oil stains have been made, neither in the field nor from the numerous core holes in this area.

Highly reflecting solid bitumen $\left(R_{0} \geq 2.5 \%\right)$ has been reported from vugs in a dolomite-calcite-quartz vein 


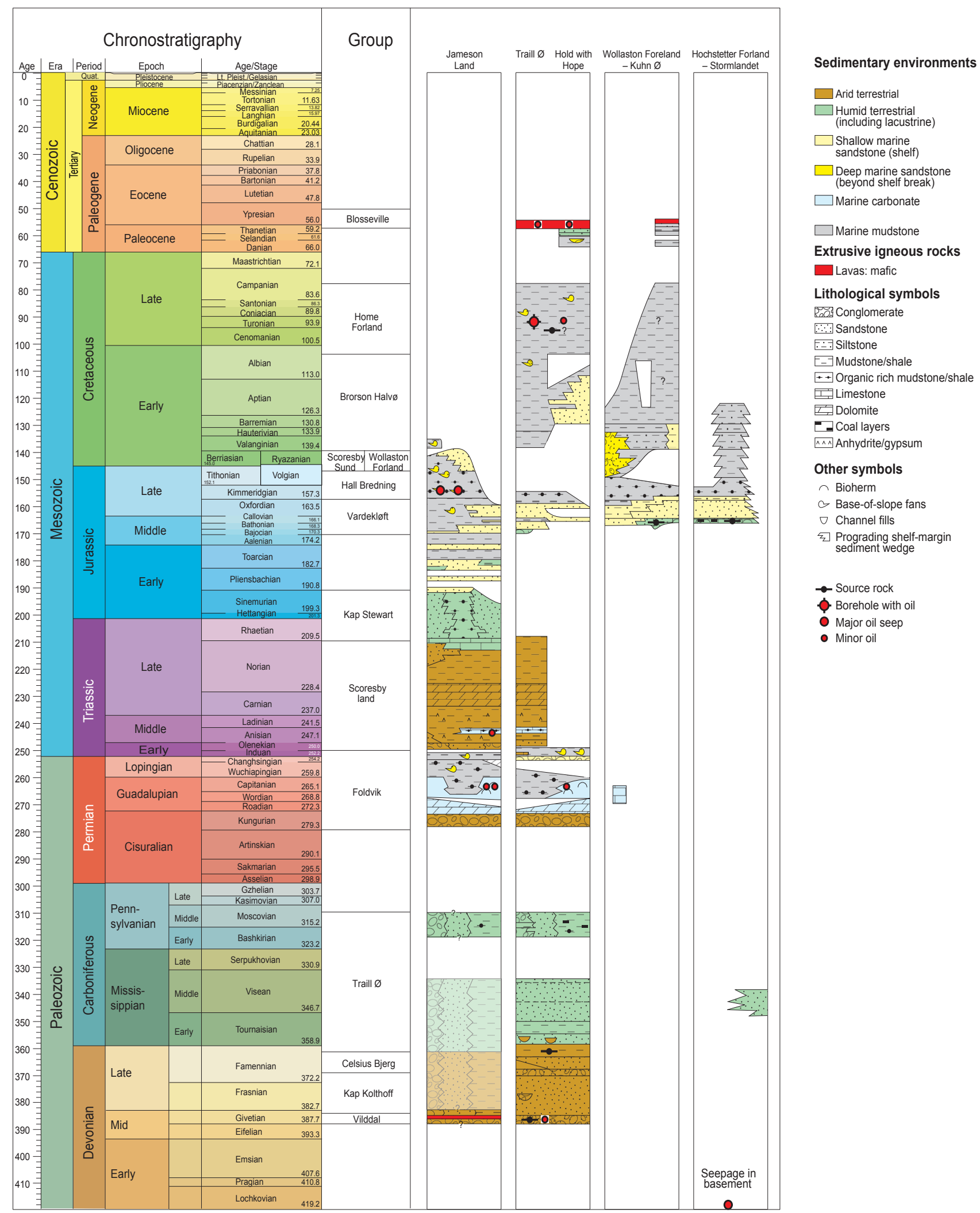

Fig. 5 Stratigraphy of East and North-East Greenland with simplified relations between petroleum seeps, stains and petroleum systems elements (modified from Christiansen et al. 1992; Fyhn et al. 2021).

in a dolomite bed from the Triassic Gråklint Member, Mols Bjerge on Traill Ø (Marcussen et al. 1987; Fig. 3L). Asphalt has also been found within fractures of the Gråklint Member and the Solfaldsdal Formation on
Buch Bjerg close to Carlsberg Fjord (Thomassen 1973; Fig. 3M).

Sandstones associated with the lacustrine source rocks in the Upper Triassic - Lower Jurassic Kap Stewart 
Group in northern Jameson Land (Dam \& Christiansen 1990) occasionally contain highly coalified bitumen near Palaeogene sills.

Dark Triassic and Jurassic sandstones with pyrobitumen have been reported at several places on Traill $\varnothing$ and Geographical Society $\varnothing$. They were described first as evidence of a paleo oil field at Laplace Bjerg (Marcussen et al. 1987) and later as large exhumed oil fields at Svinhufvud Bjerge, Mols Bjerge, Bjørnedal and Laplace Bjerg (Price \& Whitham 1997; Andrews et al. 2020a, $2020 b)$. Due to limited analytical data, very high thermal maturity (Christiansen \& Boserup 1990) and lack of non-degraded - and analytically confirmed - petroleum stains in the vicinity of these features, the model is considered controversial and has been challenged by many oil companies and GEUS geologists (Christiansen 2011; Christiansen et al. 2020b). However, as some solid bitumen has been recorded - and to make the inventory as comprehensive as possible and, importantly, to advocate for further studies - these localities have been included in the detailed locality descriptions.

Oil-stained sandstones occur in several of shallow boreholes drilled by the Geological Survey of Greenland (GGU) in the Sjællandselv area of southern Jameson Land, where the Upper Jurassic Hareelv Formation source rock has been penetrated by shallow-core drilling (Piasecki 1987; Christiansen \& Boserup 1990). The cores were studied in more detail for their organic geochemistry by Requejo et al. (1989). The same sourcerock interval was drilled in 2008 (the Blokelv-1 core), and non-degraded crude oil was noted bleeding from a belemnite (see fig. 8 in Bojesen-Koefoed et al. 2018) as well as from carbonate-lined fractures in a dolerite sill. All these oils have a composition that can be directly correlated to the Upper Jurassic Hareelv Formation source rock. Exposed oil-stained sandstones have so far not been reported in this part of Jameson Land but are likely to occur.

Jurassic sandstones of a similar age on Milne Land, west of Jameson Land, have a locally petroliferous odeur (M. Larsen, personal communication 2020). Water from streams in the same area was described as unfit for drinking and for brewing tea or coffee due to natural petroleum contamination (C. Heinberg, personal communication 1984). Perregaard \& Schiener (1979) report some effects of the intrusion of a dyke into Kimmeridgian organic-rich claystones on Milne Land, and although oil staining is not mentioned, its presence seems implicit in their findings. Their samples were originally collected in 1977 by S. Piasecki, who, however, does not recall if staining was present and does not have any notes concerning these matters in his diary. Recording potential traces of petroleum was not a priority at the time, meaning that the presence of such material cannot be ruled out (S. Piasecki, personal communication 2020).

The Nanok-1 fully cored borehole at Hold with Hope (Fig. 2B) penetrated a thick Cenomanian-Campanian succession (Bojesen-Koefoed et al. 2020). Impressive oilstained sandstones (see fig. 6 in Bojesen-Koefoed et al. 2020) occur at several intervals, and a detailed organic geochemistry suggests the presence of an underlying marine mid-Cretaceous source rock. Similar oil-stained sandstones are exposed at distances $>1 \mathrm{~km}$ from the borehole, indicating that this is a semi-regional feature.

Pale, oozing material has been reported from partially agate-filled cavities in Palaeogene basalt on Hold with Hope (W. S. Watt, personal communication 2008, 2020). Unfortunately, both the sample and extract were lost after a laboratory relocation, following a preliminary description by F. G. Christiansen and J. A. Bojesen-Koefoed. Tar-like material has been reported from a Palaeogene basalt south of Scoresby Sund close to a major fault zone (Watt \& Wrang 1984). The material is strongly degraded, but $\delta^{13} \mathrm{C}$-isotope and pyrolysis-GC data are in accordance with generation from an Upper Jurassic source rock (Requejo et al. 1989).

Petroleum seeps or stains have not been reported from the Cretaceous-Palaeogene Kangerlussuaq Basin, southern East Greenland. However, some indications of hydrocarbons from fluid inclusions in sandstones suggest local generation and migration (Jonk et al. 2005).

\subsection{Gas}

Gas seeps have not been recorded in North-East and northern East Greenland. Due to the very thick permafrost in this region, pingos mainly occur in the southern part, especially on Geographical Society $\varnothing$ and Traill $\varnothing$ (Bennike 1998). The Tobias Dal, Home Forland, hosts a few pingos. Pingos are common in the Jameson Land Basin (Bennike 1998). One poorly documented gas seep in Colorado Dal, northern Jameson Land, found and reported by the company ARCO during their exploration in the 1980s is probably from a pingo (see historic photo in Bennike 1998).

Gas kicks or free gas have not been recorded from any of the 51 fully cored boreholes drilled by GGU and GEUS in the 1980s, or more recently between 2008 and 2017. Gas from canned core pieces has been systematically analysed from many drilling locations in both East and North-East Greenland (e.g. Karlsen et al. 1988).

Gas has been observed, sampled and analysed from a hot spring in Rømer Fjord south of Scoresby Sund in the 1970s (W.S. Watt, personal communication 2020), which may suggest that the Mesozoic succession is present in the subsurface much farther south than Jameson Land. 


\subsection{Bitumen associated with mineral occurrences}

Mineralisation with bitumen in East Greenland has been recorded from some of the same geological settings that are important for the main elements of petroleum systems, for example, stratiform Cu-Pb-Zn mineralisation in the organic-rich mudstones of the Ravnefjeld Formation, previously known as the Posedonia shale, equivalent to the Kupferschiefer in Europe (Thomassen 1973; Harpøth et al. 1986). Stratiform Pb-Zn-Cu mineralisation also occurs within the thin organic-rich dolomite units of the Triassic Gråklint Member, associated with solid bitumen (Thomassen et al. 1982). Bitumen is also associated with $\mathrm{Cu}-\mathrm{Zn}-\mathrm{Pb}$ stratabound mineralisations in Permian carbonate build-ups, especially on Wegener Halvø (Thomassen et al. 1982; Harpøth et al. 1986).

Uraniferous hydrocarbons, also called carburan using the French terminology, have been reported from Devonian acid volcanic rocks from Randbøldal, Gauss Halvø (Secher \& Steenfeldt 1976; Secher et al. 1976). The carburan is found as globular grains and veinlets in cavities in the rhyolites close to faults and fracture systems, and with a close association between bitumen and uranium (A. Steenfeldt, personal communication 2020; K. Secher, personal communication 2020). The source is not documented for neither the hydrocarbons nor the uranium, albeit porphyrins in oil can carry uranium and many source rocks are enriched in uranium.

\section{Central West Greenland}

\subsection{Petroleum seeps and stains}

Petroleum seeps and stains are common in the volcanic rocks of the Nuussuaq Basin in West Greenland (Christiansen et al. 1996b; Bojesen-Koefoed et al. 1999; Christiansen et al. 2020a; Figs 1, 2C). However, before the first non-degraded oil stains were found in 1992 and further substantiated by drilling the year after at Marraat on western Nuussuaq (Christiansen 1993; Christiansen et al. 1994a, 1994b, 1996b), only few scattered observations of solid bitumen had been reported by, for example, Henderson $(1969,1976)$ and Pedersen (1986).

Since the breakthrough with drilling of the Marraat-1 well in 1993, systematic search for petroleum stains and subsequent organic geochemical analysis has been a standard procedure during many GEUS expeditions, and hundreds of samples have been collected and analysed in detail. Petroleum stains occur in a large area, at least $50 \mathrm{~km}$ by $150 \mathrm{~km}$, including parts of Disko, Hareøen, western Nuussuaq, Ubekendt Ejland, Schades Øer and Svartenhuk Halvø (Bojesen-Koefoed et al. 1999; Pedersen et al. 2008; Christiansen 2011; Christiansen et al. 2020a; Figs 1, 2C).

Petroleum exploration by a small Canadian company grønArctic Energy was partly driven by this new knowledge on petroleum seeps. Many of their drilled cores show evidence of oil or gas (Christiansen et al. 1995, 1996a; Bojesen-Koefoed et al. 1997, 1999).

As a result of this large and systematic oil hunting effort, five distinct oil types have been documented in detail and correlated to known or inferred source rocks (Christiansen et al. 1996a, 1996b, 2020a; Bojesen-Koefoed et al. 1997, 1999, 2004, 2007; Pedersen et al. 2006; Sørensen et al. 2017; Fig. 6):

1. Marraat oil type. High-wax oil with characteristic angiosperm-derived biomarkers generated from a Paleocene source rock in the Eqalulik Formation. Intense seepage and stains in a well-defined, more

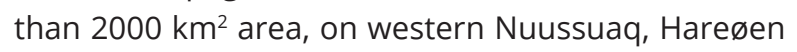
and Disko, between the Itilli and KuugannguaqQunnilik Fault zones. More than 60 samples from 25 localities including the Marraat-1, GANW\#1, GANE\#1 and GANK\#1 core holes have been analysed and documented.

2. Kuugannguaq oil type. High-wax oil generated from an inferred terrigenous Cretaceous source rock. This oil type was originally restricted to a small area on northern Disko close to or within the Kuugannguaq Fault zone. Furthermore, a number of samples collected in the Ubekendt Ejland - Svartenhuk Halvø area have been referred as to the Kuugannguaq oil type, mainly mixed with the Itilli oil type. More than 30 samples have been analysed and documented.

3. Itilli oil type. Low-wax oil generated from inferred mid-Cretaceous marine source rocks with some facies variations. This oil type is distributed throughout the Nuussuaq Basin and is the dominating type not only in the northern and westernmost parts including Ubekendt Ejland, Svartenhuk Halvø and Nuussuaq west of the Itilli Fault zone but also at Asuk on Disko. In most cases, this oil type is only found as microseepage in mineralised veins in volcanics of the Vaigat Formation. A biodegraded subtype of the Itilli oil occurs in oil-stained sandstones at Asuk on Disko. More than 60 samples from at least 30 localities have been analysed and documented. These numbers include some examples of mixing with both the Marraat, Kuugannguaq and Eqalulik oil types.

4. Eqalulik oil type. This oil type is very characteristic in composition. It was originally assumed to have been generated from a local lacustrine source rock of Early Cretaceous age, but unpublished data have made this assumption dubious. With one exception, this oil type is only found as mixtures with the Marraat oil type on Nuussuaq or with the Itilli oil type on Svartenhuk Halvø. Distribution on Nuussuaq is restricted to a minor area along the Vaigat coast, and 

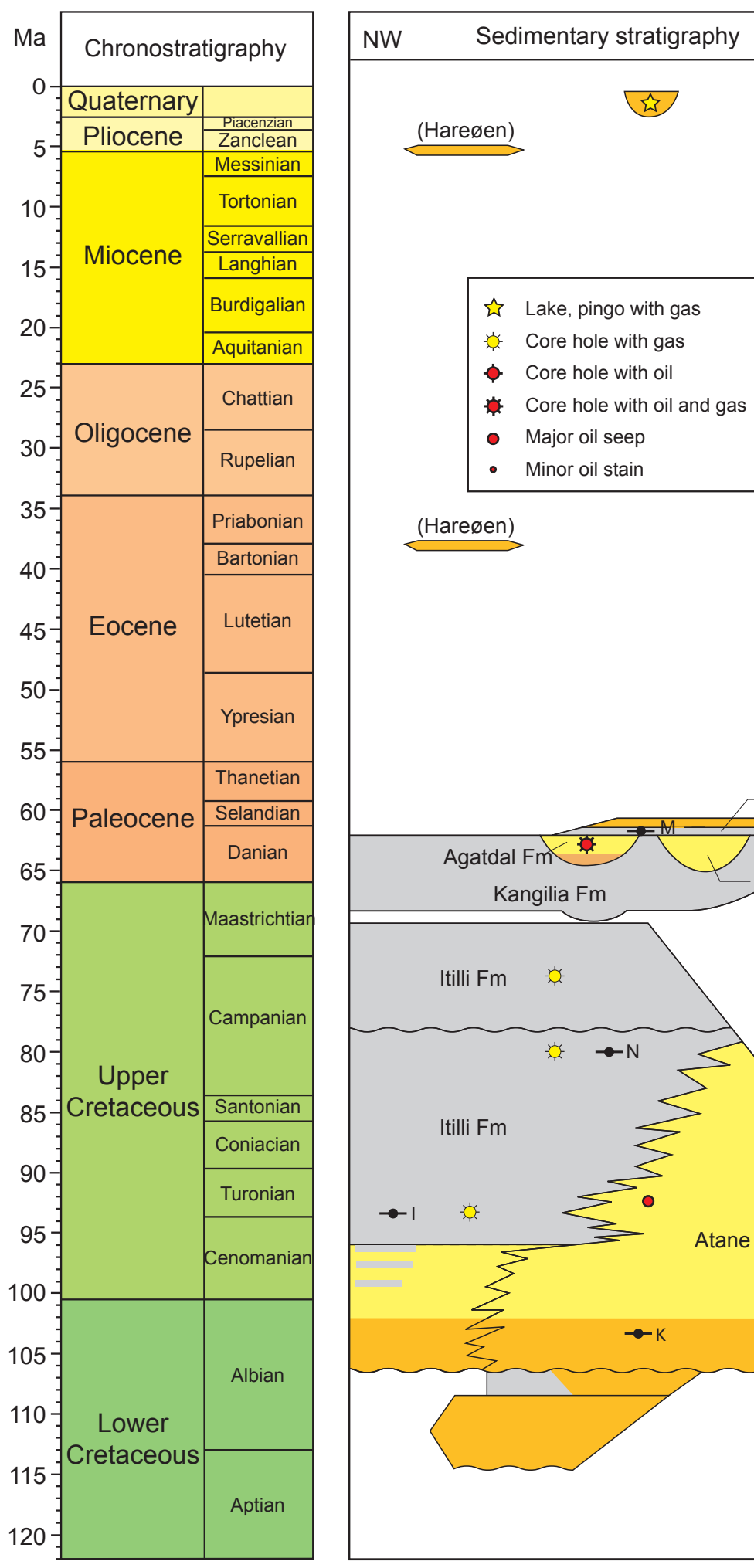

NW

Volcanic stratigraphy

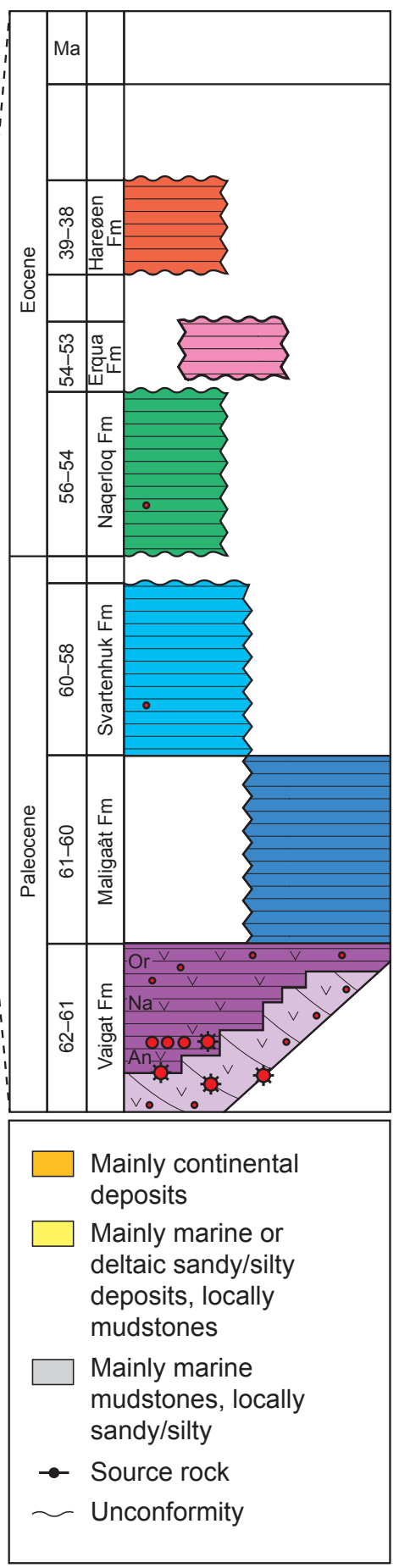

Fig. 6 Stratigraphy of West Greenland (Nuussuaq Basin) with simplified relations between petroleum seeps, stains and petroleum systems elements (based on Bojesen-Koefoed et al. 1999; Dam et al. 2009; Pedersen et al. 2017; Sørensen et al. 2017; and slightly modified from Christiansen et al. 2020a). An: Anaanaa Member. I: Itilli type. K: Kuugannguaq type. M: Marraat type. N: Niaqornaarsuk type. Na: Naujánguit Member. Or: Ordlingassoq Member.

in the GANE\#1 and GANK\#1 cores. More than 40 samples with an Eqalulik oil-type fingerprint have been analysed and documented.

5. Niaqornaarsuk oil type. High-wax oil generated from Campanian mudstones. These oil stains have only been reported from two small areas close to the Qunnilik Fault zone along the Vaigat coast and in the Aaffarsuaq valley, apparently without mixing with other oil types. More than 10 samples from six localities have been analysed and documented. 
This well-defined pattern of petroleum stains with distinct oil types and some systematic evidence of mixing provide strong indications on the distribution, facies variation and thermal maturity of the source rocks in the subsurface, and of major structural elements. Despite the large number of analysed samples from many different localities, there are still unresolved questions, especially related to details on facies variations of source rocks, how and where the different oil types migrated and mixed, and the lateral and vertical migration distances (Christiansen et al. 2020a).

\subsection{Gas}

Pingos are common in the Nuussuaq Basin (Bennike 1998). Gas seepage, gas-rich springs or lakes with bubbling gas have been in described several places over many decades (see Christiansen et al. 2020a).

Gas has also been recorded many times during core drilling by GEUS or mineral exploration companies. These observations are only included in the inventory if there is direct evidence that gas reached the surface (see Christiansen et al. 2020a for an overview, locations and geochemistry). For this reason, some gas observations from Serfat, Vismann core holes and Umiivik-1 (Dam et al. 1998) are not included in the inventory, whereas gas associated with petroleum stains in Marraat-1, GANW1, GANE\#1, GANK\#1 and GANT\#1 is described together with details of the organic geochemistry of the different oil types.

Although the analysed gases are comparatively dry, most data indicate a clear thermogenic fingerprint. Some of the sampled gases from drill holes are directly associated with specific oil stains in the penetrated sediments or volcanics, especially related to the Marraat and Eqalulik oil types (Christiansen et al. 2020a).

\subsection{Bitumen associated with mineral occurrences}

Solid pyrobitumen has been recorded in epithermal sulphide and gold mineralisations on the southern part of Ubekendt Ejland (Bernstein \& Knudsen 2004). These mineralisations in veins of the volcanic succession are relatively close to areas with non-degraded petroleum stains of the Itilli oil type or mixture with the Kuugannguaq oil types.

\section{South and southern West Greenland}

Minor traces of petroleum and hydrocarbon-rich fluid inclusions have been reported from the Ilímaussaq intrusion in South Greenland (Fig. 1; e.g. Petersilie \& Sørensen 1970; Konnerup-Madsen et al. 1979). The hydrocarbon compounds were interpreted as abiogenic until recently, when detailed organic geochemistry of extracts from the most common rock types naujaite, kakortokite and lujavrite has shown specific biomarkers characteristic of Upper Cretaceous and Paleocene source rocks farther north in West Greenland (Laier \& Nytoft 2012a, 2012b). This suggests that the petroleum recorded originated via long-distance migration during the Palaeogene from offshore sedimentary basins or hydrothermal circulation from previously overlying sediments.

The Fossilik sedimentary inlier, situated in the basement area north of Nuuk (Fig. 1), was originally interpreted as a downfaulted erosional relict (Poulsen 1966), but later reassessment showed it to represent a fallback breccia sitting in a Jurassic-age diatreme (Larsen et al. 2009). The breccia includes, among many other lithologies, a grey carbonate of Late Ordovician age with small droplets of oil. The oil is non-degraded and, based on biological marker data, is known to have been generated from a carbonate source rock (Bojesen-Koefoed 2011). The precise origin of this oil is not known, since no deposits having petroleum source potential are found in the Fossilik inlier, but it is most likely intraformational. The composition of the Fossilik oil is unique and shows little compositional similarity to any known Ordovician source rock or oil in the Arctic region.

\section{Offshore}

The offshore basins of Greenland have not been included in this inventory. Still, both conventional and shallow seismic data indicate that offshore seepage could be common in many basins. Numerous examples of possible flat and bright spots, gas chimneys, gas hydrates and pockmarks have been described in many papers, including also so-called satellite slicks indicative of seepage (e.g. fig. 4C in Bojesen-Koefoed et al. 2007; numerous figures in Cox et al. 2021; and figs. 3, 4 in Gregersen et al. 2007). However, so far neither seeping oil nor gas has been sampled and analysed from the seabed, the water column or at the water surface.

An oil-stained Ordovician-age lump of carbonate was recovered by dredging at the Davis Strait High (Dalhoff et al. 2006). The oil shows a relatively wax-rich distribution of normal alkanes, with pristane/phytane ratio less than unity. However, biological marker data do not show obvious carbonate characteristics and are dissimilar to those of the Fossilik oil stain (see Section 8). It is more than likely that future research into the offshore domain will result in numerous manifestations of petroleum migration.

\section{Conclusions and recommendations}

Petroleum seeps and stains are widespread in most Palaeozoic-Mesozoic basins in Greenland. In fact, the 
number of occurrences is striking; bearing in mind that, historically, geological mapping did not necessarily focus on manifestations of seeps, and given the permafrost conditions, which do not facilitate petroleum movement.

The seeps and stains documented here, thus, reflect the ubiquity of petroleum in the sedimentary basins of Greenland. The overview presented, thus, provides important information of past and present petroleum systems, especially concerning distribution, facies variation and thermal maturity of known or inferred source rocks. This review also provides information about migration, trapping and later degradation history. This provides important input for resource evaluations and input to new exploration models.

Documentation of basinal brines and hydrothermal circulation with petroleum compounds is also important for some mineralisation models. This is especially relevant for MVT or SEDEX occurrences in Palaeozoic basins, and stratiform mineralisation associated with organic-rich units.

Considering the size of Greenland, and the rather limited number of historic field campaigns, there is no doubt that many more petroleum seeps and stains remain to be discovered. This emphasises the old explorer's rule of thumb that 'you find what you look for'. However, the chance for finding new petroleum seeps or stains is much better today than previously. Compared to the systematic fieldwork in the 1980s and the 1990s, it is now possible to use modern satellite and airborne hyperspectral sensing tools to generate data with good proxies for petroleum seeps. In addition, advanced 3D-geological techniques can focus systematic ground control on localities that fulfil specific geological criteria or display anomalous features, which should be examined in more detail.

We see the new inventory as a modern dynamic tool that can be applied in future mineral and petroleum explorations. It also provides background documentation for research on fluid and gas movements in sedimentary basins. Furthermore, it is likely that more gas seepage will be observed in the coming years due to permafrost degradation, which, in some cases, create specific and rare ecosystems.

The first version of this inventory was based on field information from a limited number of GEUS geologists and subsequent analytical work on their samples at GEUS laboratories. We are confident that other research groups or exploration teams may have additional observations on petroleum seeps and stains in Greenland, with or without analytical evidence. We invite geologists to forward information on localities, samples, features and geological settings together with key data, references and any preserved sample material for inclusion in future versions of the inventory. It is important that such material could be systematically analysed using similar methods as previous studies by GEUS geologists, including new state-of-the-art methods where possible.

Knowing that the analytical work has been carried out over several decades and acknowledging the ongoing development and sophistication of analytical techniques and interpretation schemes, some critical samples should be reanalysed with modern techniques. For example, GCMSMS and compound specific isotope analyses could provide better oil-to-oil and oilto-source rock correlations. This will provide a better understanding of the distribution patterns of past and present mineral and petroleum systems. The samples collected previously and the extracts analysed at GEUS are, with the few exceptions where only limited material was available for a one-shot analysis, still available for future studies and applications of new methods that can provide further details on petroleum and mineral systems.

\section{Acknowledgements}

First of all thanks to all those dedicated field geologists who, on purpose or thanks to their curiosity, have made observations on petroleum seeps and stains in Greenland: Finn Dalhoff, Jon Ineson, Ulla H. Jacobsen, Hans F. Jepsen, Olav Nykjær, John S. Peel, Thomas Pletsch, Anders Pilgaard, Flemming Rolle, Diogo Rosa, Agnethe Steenfelt, Lars Stemmerik and Martin Sønderholm in North Greenland; Morten Bjerager, Gregers Dam, Svend Monrad Jensen, Mikael Larsen, Poul-Henrik Larsen, Henrik Olsen, Stefan Piasecki, Anders Pilgaard, Karsten Secher, Lars Stemmerik, Henrik Stendal, Jens Therkelsen, Bjørn Thomasen, Henrik Vosgerau and Stuart Watt in East and North-East Greenland and Greg Barnes, Stefan Bernstein, Gregers Dam, Søren Hansen, Christian Knudsen, Lotte M. Larsen, Asger K. Pedersen and Chris Pulvertaft in West Greenland. Practical help over many years and analytical support by John Boserup, Ditte Kiel-Dühring, Carsten Guvad and H. P. Nytoft are highly appreciated. The preparation of the actual web-GIS inventory and the supporting manuscript was made with much help from Ane D. Asmussen, Jette Halskov, Jonas Del Pin Hamilton, Tjerk Heijboer, Simun D. Olsen, Diogo Rosa, Lisbeth Tougaard and Willy L. Weng. Thanks to Jolanta Kus for providing unpublished information from BGR. Results are from many different field projects by GGU/GEUS with additional funding from Danish and Greenlandic authorities. Contributions came especially from the Danish Energy Research Program, the previous Mineral Resources Administration for Greenland in Copenhagen, the previous Bureau of Minerals and Petroleum in Nuuk and most recently the Department of Foreign Affairs and Energy. Support from industry in East and North-East Greenland and on Disko and Nuussuaq has been beneficial. Special appreciation is directed to Niels Henriksen, 'Oscar', the driving force behind the modern geological mapping of Greenland, leader of countless expeditions and a never-failing source of information and inspiration.

\section{Additional information}

\section{Funding statement}

The web-based GIS Inventory and the present paper were based on funding from the Department of Foreign Affairs and Energy in Nuuk and GEUS, respectively.

\section{Author contributions}

FGC: field descriptions and completion of first draft of the paper. JABK: field descriptions, paper writing and provided analytical data. 


\section{Competing interests}

The authors declare no competing interest. The authors do not accept any responsibility for the use of information provided here in future exploration.

\section{Additional files}

All additional materials with detailed locality descriptions are found in the web-based GIS inventory: https://doi.org/10.22008/FK2/JKYXJM.

\section{References}

Abrams, M.A. 2005: Significance of hydrocarbon seepage relative to petroleum generation and entrapment. Marine and Petroleum Geology 22, 457-477. https://doi.org/10.1016/j.marpetgeo.2004.08.003

Alexandre, P. \& Kyser, K.T. 2006: Geochemistry of uraniferous bitumen in the Southwest Athabasca Basin, Saskatchewan, Canada. Economic Geology 101, 1605-1610. https://doi.org/10.2113/gsecongeo.101.8.1605 Andrews, S.D., Decou, A., Braham, B., Kelly, S.R.A., Robinson, P., Morton, A., Marshall, J.E.A. \& Hyden, F. 2020a: Exhumed hydrocarbon traps on the North Atlantic Margin: Stratigraphy, palaeontology, provenance and bitumen distribution, an integrated approach. Basin Research 32(5), 1223-1243. https://doi.org/10.1111/BRE.12424

Andrews, S.D., Decou, A., Braham, B., Kelly, S.R.A., Robinson, P., Morton, A., Marshall, J.E.A. \& Hyden, F. 2020b: Exhumed hydrocarbon traps in East Greenland: Reply to Christensen et al.'s comment on Andrews et al. (2020). Basin Research 32(5), 1249-1251. https://doi.org/10.1111/ bre. 12467

Bennike, O. 1998: Pingoer. Tidsskriftet Grønland 1998, 62-68 (in Danish) Bernstein, S. \& Knudsen, C. 2004: Epithermal gold and massive sulphide mineralization in oil impregnated Palaeogene volcanic rocks of Ubekendt Ejland, West Greenland. Geological Survey of Denmark and Greenland Bulletin 4, 77-80. https://doi.org/10.34194/geusb.v4.4790

Bojesen-Koefoed, J.A. 2011: West Greenland petroleum systems. An overview of source rocks and oil seepages and their implications for offshore petroleum exploration. Danmarks og Grønlands Geologiske Undersøgelse Rapport 2011/42, 49 pp.

Bojesen-Koefoed, J., Christiansen, F. G., Pedersen, H. I., Piasecki, S. \& Stemmerik, L. 1996: Resinite-rich coals of Northeast Greenland - a hitherto unrecognized, highly oil-prone Jurassic source rock. Bulletin of Canadian Petroleum Geology 44(3), 458-473. https://doi.org/10.35767/ gscpgbull.44.3.458

Bojesen-Koefoed, J. A., Christiansen, F.G., Nytoft, H.P. \& Pedersen, A.K. 1997: Seep data from onshore West Greenland. Danmarks og Grønlands Geologiske Undersøgelse Rapport 1997/34, 7 pp., 7 figs, 8 tables.

Bojesen-Koefoed, J., Christiansen, F.G., Nytoft, H.P. \& Pedersen, A.K. 1999: Oil seepage onshore West Greenland: evidence of multiple source rocks and oil mixing. Geological Society, London, Petroleum Geology Conference Series 5, 305-314. https://doi. org/10.1144/0050305

Bojesen-Koefoed, J.A., Nytoft, H.P. \& Christiansen, F.G. 2004: Age of oils in West Greenland: was there a Mesozoic seaway between Greenland and Canada. Geological Survey of Denmark and Greenland Bulletin 4, 49-52. https://doi.org/10.34194/geusb.v4.4783

Bojesen-Koefoed, J.A., Nytoft, H.P. Christiansen, F.G. 2006: Oliefundene Nuussuaqbassinet. In: Bruun, L. et al. (eds.): Arktisk Station 1906-2006. 250-255. Copenhagen: Forlaget Rhodos. (In Danish)

Bojesen-Koefoed, J.A., Bidstrup, T., Christiansen, F.G., Dalhoff, F., Nytoft, H.P., Nøhr-Hansen, H., Pedersen, A.K. \& Sønderholm, M. 2007: Petroleum seepages at Asuk, Disko, West Greenland: implications for regional petroleum exploration. Journal of Petroleum Geology 30(3), 219-236. https://doi.org/10.1111/j.1747-5457.2007.00219.x

Bojesen-Koefoed, J.A., Alsen, P., Christiansen, F.G., Nytoft, H.P., Piasecki, S. \& Stemmerik, L. 2009: Northeast Greenland petroleum systems. Danmarks og Grønlands Geologiske Undersøgelse Rapport 2009/43, 342pp.

Bojesen-Koefoed, J.A., Alsen, P. \& Christiansen, F.G. 2014: Six years of petroleum geological activities in North-East Greenland (2088-2013). Projects and view of the future. Geological Survey of Denmark and Greenland Bulletin 31, 59-62. https://doi.org/10.34194/geusb.v31.4661

Bojesen-Koefoed, J.A., Bjerager, M., Nytoft, H.P., Petersen, H.I., Piasecki, S. \& Pilgaard, A. 2018: Petroleum potential of the Upper Jurassic Hareelv Formation, Jameson Land, East Greenland. Geological
Survey of Denmark and Greenland Bulletin 42, 85-113. https://doi. org/10.34194/geusb.v42.4314

Bojesen-Koefoed, J.A., Alsen, P., Bjerager, M., Hovikoski, J., Ineson, J., Nytoft, H.P., Nøhr-Hansen, H., Petersen, H.I., Pilgaard, A. \& Vosgerau, H. 2020: A mid-Cretaceous petroleum source-rock in the North Atlantic region? Implications of the Nanok-1 fully cored borehole, Hold with Hope, northeast Greenland. Marine and Petroleum Geology 117, 104414. https://doi.org/10.1016/j.marpetgeo.2020.104414

Burrato, P., Etiope, G., Vannoli, P., Ionescu, A. \& Martinelli, G. 2013: HYSED-IT: A database of hydrocarbon seeps in Italy. Results from MIUR/PRIN2009 project Hydrocarbon emissions from geological sources to the atmosphere in Italy. http://hydrocarbonseeps.blogspot. it/p/hysed.html (accessed July 2021)

Christiansen, F.G. (ed.). 1988: Petroleum Geology of North Greenland Final Report - 'Nordolie' (EFP 83-2251-305), Appendix II: Key data. 110 pp. Copenhagen: Geological Survey of Greenland.

Christiansen, F.G. (ed.). 1989: Petroleum geology of North Greenland. Bulletin Grønlands Geologiske Undersøgelse 158, 92 pp.

Christiansen, F.G. 1993: Disko Bugt Project 1992, West Greenland. Rapport Grønlands Geologiske Undersøgelse 159, 47-52. https://doi. org/10.34194/rapggu.v159.8207

Christiansen, F.G. 1994: Seeps and other bitumen showings: A review of origin, nomenclature and occurrences in Greenland. Open File Series Grønlands Geologiske Undersøgelse 94(7), 21 pp.

Christiansen, F.G. 2011: Chapter 42 Greenland petroleum exploration: History, breakthroughs in understanding and future challenges. In: Spencer, A. et al. (eds): Arctic Petroleum Geology. Memoir 35, 647-661. London: Geological Society. https://doi.org/10.1144/M35.42

Christiansen, F.G. \& Boserup, J. 1990: Analytical key data for assessment of the petroleum potential of the northern part of the East Greenland basin. Unpublished report for the Geological Survey of Greenland, 80 pp.

Christiansen, F.G. \& Nøhr-Hansen, H. 1989: The Silurian shales of central and western North Greenland: evaluation of hydrocarbon source rock potential. Rapport Grønlands Geologiske Undersøgelse 143, 47-71. https://doi. org/10.34194/rapggu.v143.8057

Christiansen, F.G. \& Rolle, F. 1985: Project 'Nordolie': hydrocarbon source rock investigations in central North Greenland. Rapport Grønlands Geologiske Undersøgelse 125, 17-21. https://doi.org/10.34194/rapggu. v125.7882

Christiansen, F.G. \& Stemmerik, L. 1989: Shallow core drilling of Upper Permian and Upper Triassic - Lower Jurassic potential reservoir rocks in central East Greenland. Rapport Grønlands Geologiske Undersøgelse 145 79-84. https://doi.org/10.34194/rapggu.v145.8081

Christiansen, F.G., Nykjær, O. \& Nøhr-Hansen, H. 1986: Source rock investigations and shallow core drilling in central and western North Greenland - Project 'Nordolie'. Rapport Grønlands Geologiske Undersøgelse 130, 17-23. https://doi.org/10.34194/rapggu.v130.7936

Christiansen, F.G., Nøhr-Hansen, H. \& Nykjær, O. 1987: The Cambrian Henson Gletscher Formation: A mature to postmature hydrocarbon source rock sequence from North Greenland. Rapport Grønlands Geologiske Undersøgelse 133, 141-157. https://doi.org/10.34194/rapggu.v133.7984

Christiansen, F.G., Koch, C.J.W., Nøhr-Hansen, H., Stouge, S., Thomsen, E. \& Østfeldt, P. 1989a: Chapter 6: Thermal maturity. In: Christiansen, F.G. (ed.): Petroleum Geology of North Greenland. Bulletin Grønlands Geologiske Undersøgelse 158, 40-60. https://doi.org/10.34194/bullggu. v158.6705

Christiansen, F.G., Buchardt, B., Jensenius, J., Jepsen, H.F., Nøhr-Hansen, H. \& Østfeldt, P. 1989b: Chapter 7: Bitumen occurrences. In: Christiansen, F. G. (ed.): Petroleum Geology of North Greenland. Bulletin Grønlands Geologiske Undersøgelse 158, 61-72. https://doi.org/10.34194/ bullggu.v158.6706

Christiansen, F.G., Olsen, H., Piasecki, S. \& Stemmerik, L. 1990a: Organic geochemistry of Late Palaeozoic lacustrine shales in East Greenland. Organic Geochemistry 16(1-3), 287-294. https://doi. org/10.1016/0146-6380(90)90048-5

Christiansen, F.G., Piasecki, S. \& Stemmerik, L. 1990b: Thermal maturation history of the Upper Permian succession in the Wegener Halvø area, East Greenland. Rapport Grønlands Geologiske Undersøgelse 148, 109-114. https://doi.org/10.34194/rapggu.v148.8129 
Christiansen, F.G., Bojesen-Koefoed, J., Jensen, S.M. \& Stemmerik, L. 1991: Oil seep in basement, Germania Land, North-East Greenland. Open File Series Grønlands Geologiske Undersøgelse 91/7, 29 pp.

Christiansen, F.G., Dam, G., Piasecki, S. \& Stemmerik, L. 1992: A review of Upper Palaeozoic and Mesozoic source rocks from onshore East Greenland. In: Spencer, A. M. (ed.) Generation, accummulation and production of Europe's hydrocarbons. Special Publication of the European Association of Petroleum Geoscience 2, 151-162, Heidelberg: Springer.

Christiansen, F.G., Dam, G. \& Pedersen, A.K. 1994a: Discovery of live oil at Marraat, Nuussuaq, West Greenland - field work, drilling and logging. Rapport Grønlands Geologiske Undersøgelse 160, 57-63. https://doi.org/10.34194/rapggu.v160.8232

Christiansen, F.G., Bojesen-Koefoed, J. \& Nytoft, H. P. 1994b: Organic geochemistry of oil impregnated cores from the Marraat-1 well, Nuussuaq, West Greenland - comparison with surface samples. Open File Series Grønlands Geologiske Undersøgelse 94/8, 26 pp.

Christiansen, F.G., Dam, G., Larsen, L.M., Nøhr-Hansen, H., Pedersen, A.K., Boserup, J., Bojesen-Koefoed, J., Laier, T. \& Pulvertaft, T.C.R. 1995: Stratigraphy, sedimentology and geochemistry of cores and other samples from the GANW\#1 well, Nuussuaq, West Greenland, 52 pp. Report prepared for grønArctic Energy Inc., Regina, Saskatchewan, Canada.

Christiansen, F.G., Bojesen-Koefoed, J., Nytoft, H.P. \& Laier, T. 1996a: Organic geochemistry of sediments, oils, and gases in the GANE\#1, GANT\#1, and GANK\#1 wells, Nuussuaq, West Greenland. Geological Survey of Denmark and Greenland Report 1996(23), 35 pp.

Christiansen, F.G., Bojesen-Koefoed, J., Dam, G., Nytoft, H.P., Pedersen, A.K., Larsen, L.M. \& Pulvertaft, T.C.R. 1996b: The Marraat oil discovery on Nuussuaq, West Greenland: Evidence for a latest Cretaceous Earliest Tertiary oil source rock in the Labrador Sea - Melville Bay region. Bulletin of Canadian Petroleum Geology 44(1), 39-54. https:// doi.org/10.35767/gscpgbull.44.1.039

Christiansen, F.G., Bojesen-Koefoed, J.A., Dam, G., Laier, T. \& Salehi, S. 2020a: A review of oil and gas seepage in the Nuussuaq Basin, West Greenland - Implications for petroleum exploration. GEUS Bulletin 44, 4567. https://doi.org/10.34194/geusb.v44.4567

Christiansen, F.G., Bojesen-Koefoed, J.A., Piasecki, S., Stemmerik, L. \& Therkelsen, J. 2020b: Exhumed Hydrocarbon Traps in East Greenland: A comment on Andrews et al. (2019). Basin Research 32(5), 1244-1248. https://doi.org/10.1111/bre.12463

Cox, D.R., Huuse, M., Newton, A.M.W., Sarkar, A.D. \& Knutz, P.C. 2021: Shallow gas and gas hydrate occurrences on the Northwest Greenland. Marine Geology 432, 106382. https://doi.org/10.1016/j. margeo.2020.106382

Dalhoff, F., Larsen, L.M., Ineson, J.R., Stouge, S., Bojesen-Koefoed, J.A., Lassen, S., Kuijpers, A., Rasmussen, J.A. \& Nøhr-Hansen, H. 2006: Continental crust in the Davis Strait: New evidence from seabed sampling. Geological Survey of Denmark and Greenland Bulletin 10, 33-36. https://doi.org/10.34194/geusb.v10.4901

Dam, G. \& Christiansen, F.G. 1990: Organic geochemistry and source potential of the lacustrine shales of the Late Triassic - Early Jurassic Kap Stewart Formation, East Greenland. Marine and Petroleum Geology 7, 428-443. https://doi.org/10.1016/0264-8172(90)90019-D

Dam, G., Nøhr-Hansen, H., Christiansen, F.G., Bojesen-Koefoed, J. \& Laier, T. 1998: The oldest marine Cretaceous sediments in West Greenland (Umiivik-1, Svartenhuk Halvø) - Record of the Cenomanian-Turonian anoxic event? Geology of Greenland Survey Bulletin 180, 128-137. https://doi.org/10.34194/ggub.v180.5096

Dam, G., Pedersen, G.K., Sønderholm, M., Midtgaard, H., Larsen, L.M., Nøhr-Hansen, H. \& Pedersen, A.K. 2009: Lithostratigraphy of the Cretaceous-Paleocene Nuussuaq Group, Nuussuaq Basin, West Greenland. Geological Survey of Denmark and Greenland Bulletin 19, 171 pp. https://doi.org/10.34194/geusb.v19.4886

Dawes, P.R. et al. 2000: Kane Basin 1999: Mapping, stratigraphic studies and economic assessment of Precambrian and Lower Palaeozoic provinces in north-western Greenland. Geology of Greenland Survey Bulletin 186, 11-28. https://doi.org/10.34194/ggub.v186.5211

Fyhn, M.B.W. et al. 2021: Central- and North-East Greenland Rifted Margin Composite Tectono-Sedimentary Element, From Onshore East Greenland to the Greenland Sea. In: Drachev, S. \& Moore, T. (eds): Arctic Petroleum Basins. Memoir 57, M57-2017-15. London: Geological Society. https://doi.org/10.1144/M57-2017-15
Gregersen, U., Bidstrup, T., Bojesen-Koefoed, J.A., Christiansen, F.G., Dalhoff, F. \& Sønderholm, M. 2007: Petroleum systems and structures offshore central West Greenland: Implications for hydrocarbon prospectivity. Geological Survey of Denmark and Greenland Bulletin 13, 25-28. https://doi.org/10.34194/geusb.v13.4968

Gregg, J.M. 2004: Basin fluid flow, base metal sulfide mineralization, and the development of dolomite petroleum reservoirs. In: Braithwaite, C.J.R. et al. (eds): The geometry and petrogenesis of dolomite hydrocarbon reservoirs. Special Publications 235, 157-175. London: Geological Society. https://doi.org/10.1144/GSL.SP.2004.235.01.07

Gregg, J.M. \& Shelton, K.L. 2012: Mississipi Valley-type mineralization and ore deposits in the Cambrian-Ordovician Great American Carbonate Bank. In: Derby, J.R. et al. (eds): The great American carbonate bank: The geology and economic resources of the Cambrian-Ordovician Sauk megasequence of Laurentia. 163-186. Boulder: American Association of Petroleum Geologists. https://doi.org/10.1306/13331493M981487

Gussow, W.C. 1954: Differential entrapment of oil and gas: A fundamental principle: AAPG Bulletin 38, 816-853. https://doi. org/10.1306/5ceadf11-16bb-11d7-8645000102c1865d

Harpøth, O., Pedersen, J.L., Schønwandt, H.K. \& Thomassen, B. 1986: The mineral occurrences of central East Greenland. Meddelelser om Grønland, Geoscience 17, 137 pp.

Henderson, G. 1969: Oil and gas prospects in the Cretaceous-Tertiary basin of West Greenland. Grønlands Geologiske Undersøgelse Rapport 22, 63 pp. https://doi.org/10.34194/rapggu.v22.7214

Henderson, G. 1976: Petroleum geology. In: Escher, A. \& Watt, W.S. (eds): Geology of Greenland. 488-505. Copenhagen: Geological Survey of Greenland.

Hopper, J.R. \& Ineson, J. in press: The Franklinian Composite Tectono-Sedimentary Element, North Greenland. In: Drachev, S., Henriksen, E., Moore, T. \& Harald, B. (eds): Arctic Sedimentary Basins. Memoir 57. London: Geological Society.

Hunt, J.M. 1979: Petroleum geochemistry and geology, 615 pp. San Francisco, CA: W.H. Freeman and Co.

Ionescu, A., Burrato, P., Baciu, C., Etiope, G. \& Boglarka-Mercedesz, K. 2017: Inventory of Onshore Hydrocarbon Seeps in Romania (HYSED-RO Database). Geosciences 7(2), 39. https://doi.org/10.3390/ geosciences 7020039

Jakobsen, U.H. \& Omoto, H. 1993: Bitumen associated with precipitation of sulphides in a carbonate-hosted vein mineralization, North Greenland. In: Parnell, N.J. et al. (eds.): Bitumens in ore deposits. 399-414. Berlin-Heidelberg: Springer Verlag. https://doi. org/10.1007/978-3-642-85806-2_21

Jakobsen, U.H. \& Steenfelt, A. 1985: Zinc mineralization at Navarana Fjord, central North Greenland. Rapport Grønlands Geologiske Undersøgelse 126, 105-109. https://doi.org/10.34194/rapggu.v126.7916

Jensen, S.M. 1998: Carbonate-hosted Zn-Pb-Ag mineralization in Washington Land, western North Greenland. Geology of Greenland Survey Bulletin 180, 67-72. https://doi.org/10.34194/ggub.v180.5088

Jonk, R., Parnell, J. \& Whitham, A. 2005: Fluid inclusion evidence for a Cretaceous-Palaeogene petroleum system, Kangerlussuaq Basin, East Greenland. Marine and Petroleum Geology 22(3), 319-330. https:// doi.org/10.1016/j.marpetgeo.2005.01.002

Karlsen, D.A., Leythaeuser, D. \& Schaefer, R.G. 1988: Light hydrocarbon redistribution in a shallow core from the Ravnefjeld formation on the Wegener Halvø, East Greenland. In: Matavelli, L. \& Novelli, L. (eds): Advances in Organic Geochemistry 1987, Oxford: Pergamon Press (also published as Organic Geochemistry 13, parts 1-3). Organic Geochemistry In Petroleum exploration. 393-398. Elsevier. https://doi. org/10.1016/0146-6380/88/90061-7

Konnerup-Madsen, J., Larsen, E. \& Rose-Hansen, J. 1979: Hydrocarbon-rich fluid inclusions in minerals from the alkaline llímaussaq intrusion, South Greenland. Bulletin de Minéralogie 102(5), 642-653. https://doi.org/10.3406/bulmi.1979.7313

Krabbe, H., Christiansen, F.G., Dam, G., Piasecki, S. \& Stemmerik, L. 1994: Organic geochemistry of the Lower Jurassic Sortehat Member, Jameson Land. Rapport Grønlands Geologiske Undersøgelse 164, 5-18. https://doi.org/10.34194/rapggu.v164.8266

Kus, J. \& Pletsch, T. 2012: Thermal maturity of Lower Palaeozoic sediments in western North Greenland. GeoHannover 2012, Hannover, Germany, 1-3 October. 538. 
Laier, T. \& Nytoft, H.P. 2012a: Bitumen biomarkers in the mid-Proterozoic llímaussaq intrusion, Southwest Greenland - A challenge to the mantle gas theory. Marine and Petroleum Geology 30, 50-65. https:// doi.org/10.1016/j.marpetgeo.2011.11.008

Laier, T. \& Nytoft, H.P. 2012b: New evidence for possible generation of oil off south-western Greenland. Geological Survey of Denmark and Greenland Bulletin 26, 65-68. https://doi.org/10.34194/geusb.v26.4756

Landais, P. 1993: Bitumens in uranium deposits. In: Parnell, N.J. et al. (eds): Bitumens in ore deposits. 213-238. Berlin-Heidelberg: Springer Verlag. https://doi.org/10.1007/978-3-642-85806-2_13

Landais, P. 1996: Organic geochemistry of sedimentary uranium ore deposits. Ore Geology Reviews 11(1-3), 33-51. https://doi. org/10.1016/0169-1368(95)00014-3

Larsen, L.M., Heaman, L.M., Creaser, R.A., Duncan, R.A., Frei, R., Hutchinson, M. 2009: Tectonomagmatic events during stretching and basin formation in the Labrador Sea and the Davis Strait: Evidence from age and composition of Mesozoic to Palaeogene dyke swarms in West Greenland. Journal of the Geological Society, London 166, 999-1012. https://doi.org/10.1144/0016-76492009-038

Link, W.K. 1952: Significance of oil and gas seeps in World exploration. AAPG Bulletin 36, 1505-1540. https://doi. org/10.1306/5ceadb3f-16bb-11d7-8645000102c1865d

Macgregor, D.S. 1993: Relationships between seepage, tectonics and subsurface reserves. Marine and Petroleum Geology 10, 606-619. https://doi.org/10.1016/0264-8172(93)90063-X

Marcussen, C., Christiansen, F.G., Larsen, P.H., Olsen, H., Piasecki, S., Stemmerik, L., Bojesen-Koefoed, J., Jepsen, H.F. \& Nøhr-Hansen, H. 1987: Studies on the onshore hydrocarbon potential in East Greenland 1986-87: Field work from $72^{\circ}$ to $74^{\circ} \mathrm{N}$. Rapport Grønlands Geologiske Undersøgelse 135, 72-81. https://doi.org/10.34194/rapggu.v135.8002

Mikkelsen, A. 1993: Grønlands 'lovende oliefund'. Tidsskriftet Grønland 1993(7), 307-311. (In Danish)

Palabiyik, Y. \& Ozdemir, A., 2019: Oil and gas seeps in Turkey: A review. 7th International Symposium on Academic Studies in Science, Engineering and Architecture Sciences, Ankara, Turkey, 15-17 November 2019, 726-740.

Paradis, S., Hannigan, P. \& Dewing, K. 2007: Mississippi Valley-type leadzinc deposits. In: Goodfellow, W.D. (ed): Mineral deposits of Canada: A synthesis of major deposits-types, district metallogeny, the evolution of geological provinces, and exploration methods. Special Publication 5, 185-203. Geological Association of Canada, Mineral Deposits Division. St. John's, Newfoundland

Parnell, J. 1988: Metal enrichment in solid bitumens: A review. Mineralium Deposita 23, 191-199. https://doi.org/10.1007/BF00204301

Pedersen, A.K. 1986: Indication of migrated hydrocarbons in Tertiary volcanic rocks from western Nûgssuaq, Rapport Grønlands Geologiske Undersøgelse 130, 32-35. https://doi.org/10.34194/rapggu. v130.7938

Pedersen, A.K., Larsen, L.M., Pedersen, G.K. \& Dueholm, K.S. 2008: Geological map of the area around Sikillingi, western Nuussuaq, central West Greenland, 1:20 000. Copenhagen: Geological Survey of Denmark and Greenland.

Pedersen, A.K., Larsen, L.M. \& Pedersen, G.K. 2017: Lithostratigraphy, geology and geochemistry of the volcanic rocks of the Vaigat Formation on Disko and Nuussuaq, Paleocene of West Greenland. Geological Survey of Denmark and Greenland Bulletin 39, 244 pp. https://doi. org/10.34194/geusb.v39.4354

Pedersen, G.K., Andersen, L.A., Lundsteen, E.B., Petersen, H.I., Bojesen-Koefoed, J.A. \& Nytoft, H.P. 2006: Depositional environments, organic maturity and petroleum potential of the Cretaceous coal-bearing Atane Formation at Qullissat, Nuussuaq Basin, West Greenland, Journal of Petroleum Geology 29(1), 3-26. https://doi. org/10.1111/j.1747-5457.2006.00003.x

Perregaard, J. \& Schiener, E.J. 1979: Thermal alteration of sedimentary organic matter by a basalt intrusive (Kimmeridgian shales, Milne Land, east Greenland). Chemical Geology 26(3-4), 331-343. https:// doi.org/10.1016/0009-2541(79)90055-X

Peters, K.E., Walters, C.C. \& Moldowan, J.M. 2004: The biomarker guide, 2nd edition, 1155 pp. Cambridge: Cambridge University Press. https:// doi.org/10.1017/CBO9781107326040
Petersen, H.I., Bojesen-Koefoed, J.A. \& Nytoft, H.P. 2002: Source rock evaluation ofMiddleJurassiccoals, northeastGreenland, byartificialmaturation: Aspects of petroleum generation from coal. AAPG Bulletin 86, 233-256. https://doi.org/10.1306/61EEDA9E-173E-11D7-8645000102C1865D

Petersen, H.I., Øverland, J.A., Solbakk, T., Bojesen-Koefoed, J.A. \& Bjerager, M. 2013: Unusual resinite-rich coals found in northeastern Greenland and along the Norwegian coast: Petrographic and geochemical composition, International Journal of Coal Geology 109-110, 58-76. https://doi.org/10.1016/j.coal.2013.02.001

Petersilie, I.A. \& Sørensen, H. 1970: Hydrocarbon gases and bituminous substances in rocks from the llímaussaq alkaline intrusion, South Greenland. Lithos 3(1), 59-76. https://doi.org/10.1016/0024-4937(70)90088-5

Piasecki, S. 1987: LECO/Rock-Eval screening analysis of the Upper Paleozoic - Mesozoic sediments of Jameson Land, central East Greenland. Unpublished report for the Geological Survey of Greenland. 72 pp. Cambridge: Cambridge University Press.

Piasecki, S., Christiansen, F.G. \& Stemmerik, L. 1990: Depositional history and organic geochemistry of Carboniferous lacustrine deposits in East Greenland. Bulletin of Canadian Petroleum Geology 38(3), 273-287. https://doi.org/10.35767/gscpgbull.38.3.273

Poulsen, V. 1966: An occurrence of Lower Palaeozoic rocks within the Precambrian terrain near Sukkertoppen. Rapport Grønlands Geologiske Undersøgelse 11, 26. https://doi.org/10.34194/rapggu.v11.7143

Price, S.P. \& Whitham, A.G. 1997: Exhumed hydrocarbon traps in East Greenland: Analogs for the Lower-Middle Jurassic Play of North West Europe. AAPG Bulletin 81, 196-221. https://doi. org/10.1306/522b42e9-1727-11d7-8645000102c1865d

Requejo, A.G., Hollywood, J. \& Halpern, H.I. 1989: Recognition and source correlation of migrated hydrocarbons in Upper Jurassic Hareelv Formation, Jameson Land, East Greenland. AAPG Bulletin 73, 1065-1088. https://doi.org/10.1306/44B4A53C-170A-11D7-8645000102C1865D

Scholle, P.A., Stemmerik, L. \& Ulmer, D.S. 1991: Diagenetic history and hydrocarbon potential of Upper Permian carbonate build-ups, Wegener Halvø area, Jameson Land basin, East Greenland. AAPG Bulletin 75, 701725. https://doi.org/10.1306/0C9B2835-1710-11D7-8645000102C1865D

Schumacher, D. \& Abrams, M.A. (eds.). 1996: Hydrocarbon migration and its near surface expression. 446 pp. Boulder: American Association of Petroleum Geologists. https://doi.org/10.1306/M66606

Secher, K. \& Steenfelt, A. 1976: Foreløbig rapport over malmmikroskopisk og mineralogisk undersøgelse af radioaktiv mineraliseringer i Randbøldal, Østgrønland. Unpublished report for the Geological Survey of Greenland, 33 pp + appendices. Copenhagen: Geological Survey of Greenland (In Danish)

Secher, K., Nielsen, B.L. \& Steenfelt, A. 1976: Uraniferous hydrocarbons (Carburan) associated with Devonian acid volcanic rocks, Randbøldal, northern East Greenland. Rapport Grønlands Geologiske Undersøgelse 80, 112-115. https://doi.org/10.34194/rapggu. v80.7501

Selley, R.C. 1992: Petroleum seepages and impregnations in Great Britain. Marine and Petroleum Geology 9, 226-244. https://doi. org/10.1016/0264-8172(92)90072-M

Stemmerik, L., Scholle, P.A., Thomas, E., Amondolina, M., Henk, F.M. \& Uncini, G. 1989: Facies mapping and reservoir evaluation of the Upper Permian Wegener Halvø Formation in Wegener Halvø, East Greenland. Rapport Grønlands Geologiske Undersøgelse 145, 84-87. https://doi.org/10.34194/rapggu.v145.8082

Stemmerik, L., Christiansen, F.G. \& Piasecki, S. 1990: Carboniferous lacustrine shales in East Greenland - an additional source rock in the northern Atlantic? In: Katz, B. (ed.): Lacustrine exploration: case studies and modern analogues. AAPG Memoir 50, 277-286. https:// doi.org/10.1306/m50523c17

Stemmerik, L., Sønderholm, M. \& Bojesen-Koefoed, J. 1997: Palaeo-oil field in a Silurian carbonate buildup, Wulff Land. Geology of Greenland Survey Bulletin 176, 24-28. https://doi.org/10.34194/ggub.v176.5056

Sørensen, E.V., Hopper, J.R., Pedersen, G.K., Nøhr-Hansen, H., Guarnieri, P., Pedersen, A.K. \& Christiansen, F.G. 2017: Inversion structures as potential petroleum exploration targets on Nuussuaq and northern Disko, onshore West Greenland. Geological Survey of Denmark and Greenland Bulletin 38, 45-48. https://doi.org/10.34194/geusb. v38.4406 
Thomassen, B. 1973: Heavy metal content of the Posidonia Shales on Wegener Halvø. Rapport Grønlands Geologiske Undersøgelse 58, 33-35. https://doi.org/10.34194/rapggu.v58.7361

Thomassen, B., Clemmensen, L.B. \& Schønwandt, H.K. 1982: Stratabound copper-lead-zinc mineralisation in the Permo-Triassic of central East Greenland. Bulletin Grønlands Geologiske Undersøgelse 143, 42 pp. https://doi.org/10.34194/bullggu.v143.6685

Thrane, K. \& Kalvig, P. 2019: Graphite potential in Greenland. Geology and Ore 32, $12 \mathrm{pp}$.

Van der Stijl, F.W. \& Mosher, G.Z. 1998: The Citronen Fjord massive sulphide deposit, Peary Land, North Greenland: Discovery, stratigraphy, mineralization and structural setting. Geology of Greenland Survey Bulletin 179, 40 pp. https://doi.org/10.34194/ggub.v179.6270
Von Guttenberg, R. \& van der Stijl, F. 1993: North Greenland Project 1992. Report of Work. Unpublished company report. Nanisivik Mines Ltd., Platinova A/S. 129 pp. Toronto.

Watt, W.S. 2019: Stratigraphic lexicon for Greenland. 327 pp. Copenhagen: Geological Survey of Denmark and Greenland. https://doi. org/10.22008/geusbook/strat-lex-greenland

Watt, W.S. \& Wrang, P. 1984: Migrated hydrocarbons in basalt on the south side of Scoresby Sund. Rapport Grønlands geologiske Undersøgelse 120, 84-85. https://doi.org/10.34194/rapggu.v120.7863

Zheng, G., Xua, W., Etiope, G., Ma, X., Liangd, S., Fana, Q., Sajjada, W. \& Lia, Y. 2018: Hydrocarbon seeps in petroliferous basins in China: A first inventory. Journal of Asian Earth Sciences 151, 269-284. https://doi. org/10.1016/j.jseaes.2017.10.037 